\title{
Multinational investments across Europe: a multilevel analysis
}

\author{
Jonas Kleineick ${ }^{1} \cdot$ Andrea Ascani $^{2}$ (D) $\cdot$ Martijn Smit $^{3}$
}

Accepted: 1 April 2020 / Published online: 9 April 2020

(C) The Author(s) 2020

\begin{abstract}
This research focuses on the investigation of the location determinants of multinational corporations' investments in EU countries. Investment projects are addressed by making a distinction between greenfield investments and M\&A projects. Besides traditional factors (such as market characteristics) the effect of innovation capabilities and the institutional environment are incorporated in the analysis. The use of a multilevel model makes it possible to empirically assess the effect of national and regional characteristics on the location decision of multinationals. The results suggest that greenfield investments and M\&A are similar in their location determinants, although the former have a stronger correlation with highly educated populations. Urbanisation, associated with land cost, as well as national (rather than regional) markets are insignificant. Finally, we find no evidence for the importance of political stability within Europe.
\end{abstract}

Keywords Multinationals · Investment · Regions · European Union

JEL classification $\mathrm{F} 23 \cdot \mathrm{F} 21 \cdot \mathrm{R} 12 \cdot \mathrm{N} 14$

M. Smit

m.j.smit@uu.nl

1 Düsseldorf, Germany

2 Social Sciences, Gran Sasso Science Institute, L'Aquila, Italy

3 Dept. of Human Geography \& Spatial Planning, Utrecht University, Princetonlaan 8a, room 6.88, 3584 CB Utrecht, The Netherlands 
Zusammenfassung Diese Studie beschäftigt sich mit den Faktoren, die die Standortwahl multinationaler Unternehmen in ihrem Investitionsverhalten beeinflussen. Ausländische Direktinvestitionen werden im Kontext dieser Arbeit unterteilt in Greenfied Projekte und Fusionen und Übernahmen (M\&A). Neben traditionellen Standortfaktoren (wie beispielsweise Markteigenschaften) wird im Rahmen dieses Artikels der Effekt der regionalen Innovationsfähigkeit und der institutionellen Rahmenbedingen untersucht. Die Verwendung einer Mehrebenenanalyse ermöglicht es empirisch den Effekt von sowohl nationalen als auch regionalen Faktoren in Bezug auf die Standortwahl multinationaler Unternehmen näher zu betrachten. Standortfaktoren, die Greenfield und M\&A-Projekte beeinflussen, weisen große Ähnlichkeit auf, wenn gleich Greenfield Investitionen eine stärkere Korrelation mit dem Bildungsniveau der Bevölkerung aufweist. Urbanisierung und die damit verbundenen Grundstückskosten, wie auch die nationale (anders als die regionale) Marktgröße zeigen keinen signifikanten Effekt auf. Abschließend konnte keine Evidenz für einen Effekt der politischen Stabilität auf die standörtliche Wahl multinationaler Unternehmen in Europa gefunden werden.

\section{Introduction}

In recent years, many observers in both policy and academic circles argue that foreign direct investment (FDI) is of growing importance for the economic performance of countries and regions as it plays a primary role in the global (re)organisation of production (WTO 1996; Dicken 2007; Yeung and Coe 2015; Iammarino 2018). In a firm perspective, Multinational Companies (MNCs) constantly make decisions that are related to the search for new locations, by acquiring or merging with other firms (Guadalupe et al. 2012; Ascani 2018) or by setting up entirely new plants abroad (Head and Mayer 2004). Considering that these decisions can have a significant economic impact on recipient locations (e.g. Bellak et al. 2008; Ascani and Gagliardi 2015), the attraction of FDI has rapidly gained centre stage in the agenda of policy makers all over the world. This primarily implies that countries and regions become more appealing for the activities of MNCs. In fact, a healthy and enabling environment for business is needed in order successfully attract global FDI, retain it over time and maximise the gains associated with its presence (OECD 2002). Indeed, a vibrant business environment encourages both domestic and foreign investment, it stimulates innovation and the accumulation of skills, as well as it contributes to a more competitive climate.

Although prior academic works have devoted a large effort to understand the entry choice of MNCs (e.g. Nocke and Yeaple 2007; Raff et al. 2009; Becker and Fuest 2011) as well as their role in fostering economic development, growth and innovation (e.g. Liu and Zou 2008; Wang and Wong 2009), most studies either focus on single-country cases or only concentrate on a narrow set of location determinants and mostly adopt an a-spatial lens of analysis. In this context, the objective of this research is not only to provide novel insights into the factors that affect the location strategies of MNCs, but also to produce an integrated framework of analysis of MNCs' location decisions of greenfield FDI and M\&A, by building on and 
expanding the findings of recent contributions (e.g. Crescenzi et al. 2014; Ascani et al. 2016). By means of a quantitative analysis of the location factors that influence the geography of European MNCs' investment projects within the EU over the period 2012-2017, therefore, this paper integrates in a unified theoretical and empirical framework the (i) traditional location factors of foreign investment with (ii) the innovation capabilities of regions, as well as (iii) their institutional contexts. Integrating these diverse elements also calls for a careful consideration of the heterogeneous spatial levels at which every pull factor of global FDI operates, as some locational determinants have an inherently local flavour while others are connected to country-level considerations (Iammarino and McCann 2013). Furthermore, the changing composition of FDI in the EU in recent years with the share of foreign firms producing manufacturing goods declining over time, and the number of foreign firms providing services increasing (Capello et al. 2011) requires a careful investigation of the different location choices by adopting a fine-sliced division of the different economic activities, as there can be remarkable differences in the location determinants of manufacturing plants and service facilities (Py and Hatem 2009).

This research, hence, aims at contributing to the current academic debate in at least four respects. First, it introduces a third set of explanatory variables (i.e. institutional factors) in the framework used by Crescenzi et al. (2014), in consideration of the findings of Bartik (1985), Ang (2008), Bellak and Leibrecht (2009) and Ascani et al. (2016), who all provide evidence that the institutional environment of recipient locations matters for the location decision of MNCs. Hence, this research aims at providing a comprehensive analysis of the location determinants of MNCs' investment projects. Second, the present analysis of FDI location determinants is not limited to greenfield projects, as customary in the literature on firm location choices, but we extend our reach by accounting for M\&A. Previous contributions, in fact, suggest that the location determinants strongly differ according to the entry mode of the foreign company (e.g. Basile 2004). Third, this research provides insights at the local level, thus narrowing down the analysis within countries, by including data on NUTS3 level for multiple nations, as advocated by recent studies on MNCs and FDI (Iammarino and McCann 2013; Iammarino 2018). The existing academic literature on the location determinants of MNCs, instead, mainly consists of national-level studies (e.g. Devereux and Griffith 1998b; Cleeve 2008; Mohamed and Sidiropoulos 2010; Ascani et al. 2016). Besides, several contributions have included data on the subnational level for NUTS1 regions (e.g. Basile et al. 2008) or NUTS2 (e.g. Cantwell and Piscitello 2005; Crescenzi et al. 2014), or US subnational units (e.g. Head et al. 1995, 1999). Only a limited number of studies employ data at a lower geographical level than NUTS2, including Guimaraes et al. (2000) and Crozet et al. (2004) who provide an analysis of the location choices of MNCs using data on NUTS3 regions for Portugal and France, respectively. However, there is a relevant lack of empirical evidence employing such a geographical level of data refinement for multiple countries or for political and economic unions comparable to the EU. Hence our research also aims at filling this gap by providing insights about the location determinants of MNCs' investment projects across the EU at the NUTS3 spatial scale. Last but not least, the scope of the dataset used in this research is not limited to one level of analysis only, since this research also takes into account 
factors operating at the national level shaping the decisions of MNCs. This hierarchical structure of the data requires the use of a multilevel model (MLM), which allows for the introduction of factors on two or more levels of observation. Through the application of this methodological approach, this research aims to offer new, comprehensive and original insights into the location determinants of foreign direct investment projects within the EU.

This article is structured as follows: the next section establishes the theoretical background of the study by reviewing and contextualizing the previous literature on the location choices of MNCs. Subsequently, the data for the empirical analysis is presented and the methodological framework is described. Next, we discuss the results of different multilevel models. Finally, we offer some concluding remarks and recommendations for further research.

\section{Theoretical background}

In this section we first address the MNC choice of entry into foreign markets, by describing the cases of greenfield FDI and M\&A. Subsequently, we discuss the role, sectoral composition and spatial scale of the traditional location drivers, the regional innovation capabilities and the institutional factors that the literature on MNCs' location strategies has investigated. In so doing our aim is to integrate these different perspectives into a conceptual model that provides the basis for our empirical investigation.

\subsection{The entry mode: Greenfield investments and M\&A projects}

An extensive body of academic literature focuses on the location decisions of MNCs. A traditional approach to this is the well-known Ownership-Location-Internalisation paradigm (OLI), introduced by Dunning $(1977,1979)$, according to which the decision of companies to undertake foreign investment is based on the co-occurrence of three set of advantages: firm-specific advantages that arise from owning certain key resources, such as knowledge (Ownership), Location-advantages that are associated with the host region of the investment (e.g. resources, labour force) and, finally, Internalisation-advantages deriving from the benefits associated to the exploitation of the firm-specific advantages within the company boundaries at the chosen foreign location. Greenfield FDI represents the typical form of foreign engagement referring to the combination of these three sets of advantages, involving the establishment of entirely owned subsidiaries in a new geographic market (Wang and Wong 2009, Bertrand et al. 2007). As such, these greenfield ventures provide the highest form of control over internal resources and knowledge but are also likely to have the highest costs (Hennart and Park 1994). These costs include the establishment of both, the physical facilities and the relationships and networks that are necessary to operate effectively (Andersson et al. 1997).

As an addition to the three above-mentioned motives of the Ownership-Location-Internalisation paradigm, Cantwell (1989) considers that rather than utilizing capabilities already at hand, companies can invest abroad in search of capabilities 
that are not available in their home markets, thus undertaking "knowledge seeking" investments. Consequently, MNCs may supplement their firm specific technologies by expanding internationally to access new localized knowledge (Ascani 2018), since some knowledge is partially tacit and the transfer requires frequent interaction (Kogut and Zander 1992; Boschma 2005).

MNCs, in fact, can use M\&A as an alternative entry mode in order to facilitate their internationalisation strategy. This type of investment is defined as the take-over of (a part of) the assets of already established businesses abroad (Ó hUallacháin and Reid 1997). Through that, the acquiring firm obtains the resources of the target firm, such as its knowledge base, technology and human resources, and it also gains access to the new market and to key constituencies at local level (Newburry and Zeira 1997; Iammarino and McCann 2013).

The decision about the internationalisation strategy of a business is closely related to the growth strategy of the company (Wang 2009a). Greenfield investment is the most typical way to exploit the advantages of internal growth, while M\&A is related to external growth (Wang 2009b). Therefore, greenfield FDI can be attractive when firm-specific technological and organisational competences define a firm's ability to compete on the market, since the company has the possibility to duplicate (parts of) their know-how, their routines, and the physical property (Hennart and Park 1993) across locations. If a company, instead, aims at (immediate) access to the technologies and the local market experience of a target firm, a takeover can be preferable (Ó hUallacháin and Reid 1997; Cantwell and Santangelo 2002). M\&A projects, therefore, seem to be a less risky entry mode compared to greenfield investment.

Although the decomposition of FDI shows that M\&As constitute the bulk of FDI (Brakman et al. 2007), there is strong academic evidence that greenfield projects can be more favourable for economic growth and development in the host region (Javororcik and Kaminski 2009; Neuhaus 2005; Miskinis and Byrka 2014). Reasons for that can especially be found in the direct effects of this type of investment that have impact on capital formation, technological and innovative progress, employment, and human resource development and the indirect effects that arise from spillovers, leading to competitive and productivity growth in the host region. Importantly, the location determinants of foreign subsidiaries can differ according to the entry mode (Basile 2004), and since the present research aims at providing insights on the location determinants of MNCs' investment projects, it is important to not limit the analysis to greenfield FDI, but also to take into account M\&A projects.

\subsection{Traditional location determinants}

With respect to the location determinants of MNCs' investment projects, traditional approaches to the analysis of this topic have alternatively included a number of factors. Early studies, such as Head et al. (1995, 1999), Guimaraes et al. (2000) and Crozet et al. (2004), consider the cumulative nature of foreign direct investment as an important determinant of a firm's location choice, thus highlighting that previous investment in the same industry or from the same country of origin positively influences the probability of additional investment in the same area. This 
type of agglomeration dynamics is explained by inter-firm technological spill-overs, the availability of specialised labour, and the access to intermediate inputs within the value chain, echoing the work of Marshall (1920). In a similar vein, Head and Mayer (2004) suggest that market access considerations of MNCs are also crucial, indicating that foreign firms also tend to locate where the concentration of local demand is high. Market size and market growth constitute, indeed, a recurrent traditional motive in most analyses (Schneider and Frey 1985; Wheeler and Mody 1992; Head and Mayer 2004; Botrić and Škuflić 2006; Basile et al. 2008; Cleeve 2008; Mohamed and Sidiropoulos 2010).

With respect to the effect of labour market conditions on the location choice of foreign subsidiaries the findings in the academic literature remain mixed, with some studies suggesting a positive relationship between labour costs and the number of foreign subsidiaries of MNCs (e.g. Guimaraes et al. 2000; Defever 2006), and others concluding that this relationship remains weak (Woodward 1992; Devereux and Griffith 1998; Head et al. 1999; Head and Mayer 2004) or even negative (Botrić and Škuflić 2006; Py and Hatem 2009). A possible explanation for these different findings might be that, on the one hand, higher wages can reflect the availability of skilled workers, therefore having a positive effect, but, on the other hand, higher wages lead to an increase in costs of companies, therefore having a negative effect. Similarly, the unemployment rate can refer to high availability of labour (positive effect on FDI as in Botrić and Škuflić 2006; Py and Hatem 2009), but also to a lack of suitable work force (c.f. Disdier and Mayer 2004). Possibly, these differences can be caused by differences in terms of the type of activity that is relocated in a foreign region.

Finally, some studies use measurements of urbanisation in order to estimate the effect of metropolitan areas and land costs on the attraction of foreign direct investment. The results of Basile (2004) also show a positive impact of urbanisation on the number of MNCs' foreign subsidiaries, suggesting that agglomerations of consumers make regions more attractive for foreign investors.

\subsection{Regional innovation capabilities}

The second set of factors which has an effect on the location decision of MNCs can be considered as innovation capabilities of a region. Crescenzi et al. (2014) argue that this set of factors is frequently overlooked in recent quantitative contributions, while it has rather become the focus of in-depth case studies. However, the latter type of studies, while exploring the nuances of the dynamics at hand for a specific case, have a low degree of generality compared to more formal quantitative research (Cantwell and Iammarino 2003). In order to fill this gap, Crescenzi et al. (2014) quantitively consider the regional endowment of innovation capabilities as a location determinant of foreign MNCs and detect a positive effect on the attraction of MNCs' investments in EU-25 countries, which is in line with the existing literature on regional innovation (Pike et al. 2006). Beside the very limited number of studies accounting for innovation-related factors at the regional level on the location decision of MNCs, several studies have focused on this relationship at the national level. Dunning (2013), for instance, argues that MNCs prefer to invest in regions with 
a high regional productivity. This argumentation assumes that wage rates rise with productivity growth, yet at a slower pace than the productivity growth. According to Dunning (2013) this means that a higher rate of productivity growth leads to a decrease in unit costs and an increase in profitability and international competitiveness, making more productive regions more attractive for foreign investments. Cleeve (2008) finds in his research about the attraction of FDI to sub-Saharan Africa that human capital has the expected positive effect on the location decision of foreign investors. Similarly, Ascani et al. (2016) conclude that there is a significant relation between the educational level and the attraction of MNC's foreign subsidiaries.

\subsection{Institutional factors}

Several studies take an institutional approach as a starting point in order to analyse the geography of MNCs. According to this approach, the institutional environment of a region or a country matters for the location decision of MNCs. However, in the academic literature there are many different ways to include this institutional perspective in the empirical analysis. A number of contributions focuses on government corruption as a factor influencing MNCs strategies, suggesting that highly corrupted authorities discourage inward FDI (Asiedu 2006; Cleeve 2008; Du et al. 2008; Mohamed and Sidiropoulos 2010). The taxation level of host locations has also received strong attention as an institutional factor. Starting with Hartman (1984), most studies show that FDI is strongly sensitive to taxation. For example, by using sub-national data on FDI inflow in Malaysia, Ang (2008) concludes that the statutory corporate tax rate has a significant negative effect on the total number of FDI. This is in line with the findings of Head et al. (1995) about the location of Japanese investment in the EU. Bellak and Leibrecht (2009) also take taxation into account while studying the determinants of foreign direct investment in central and eastern European countries, by considering the effective average tax rate (EATR), since the EATR is a conceptually accurate measure of the corporate income tax burden when analysing the effect of taxation on the location decision of MNCs. Their findings suggest that taxation has the expected negative effect on the FDI volume. Buettner and Ruf (2007) exclusively focus on the effect of different types of taxes on the location of FDI. Contrary to the findings of Bellak and Leibrecht (2009) they conclude that the statutory corporate income tax rate, rather than the EATR, functions as a determinant for the location decision of German multinationals. Moreover, Ascani et al. (2016) uses a business regulation index that contains different types of costs associated with-inter alia-taxes. Based on their findings they conclude that this index has a significant positive effect on the location decisions of MNCs, which corresponds to their expectations, since a higher index reflects a less regulated institutional environment.

Besides corruption and taxation, several other factors are considered by various studies in order to address the institutional approach while analysing the location decision of MNCs. In order to measure the institutional environment, Asiedu (2006) includes the effectiveness of the rule of law and concludes that this factor has the expected positive effect on the attraction of FDI. Cleeve (2008) combines political freedom and civil liberty into one institutional index and concludes that this index 
does not have a significant effect on the attraction of MNCs. Based on the findings in the existing academic literature it has become clear that there is to some extent disagreement about the impact of institutional factors on the location decision of MNCs.

\subsection{Conceptual model}

As a result of the previous discussion, we integrate the main findings of the literature into the conceptual model in Fig. 1. This model contains all the factors that have a significant impact on the location decision of MNCs. The model considers the concurrent and hierarchical role of different sets of location factors influencing the strategic entry choices of MNEs. At the same time, these factors operate at multiple spatial scales, namely national and local.. In the upper segment of Fig. 1 the institutional factors are included in the model. According to previous studies these factors can play an important role for the location decision of MNCs. However, the existing literature does not indicate which set of factors has the greatest impact on the location choice of MNCs. In this research we consider that institutional factors can affect the opportunity of MNCs to engage in a foreign market, thus influencing their location strategies. These factors are measured on national level, as most institutional structures refer to country-wide rules and norms. In the middle segment of Fig. 1, traditional location factors encompass a plethora of drivers of MNC activity, ranging from market access considerations to agglomeration and efficiency rationales. In these terms, most of these elements operate at the regional scale as the decisions of MNCs regard the specific subnational economic geography of countries (Iammarino and McCann 2013). Nevertheless, we consider also that the market size of the recipient country can be a relevant factor of attraction at the national scale as demand linkages can transcend regional boundaries. The third segment of Fig. 1 includes, finally, the innovation capabilities of regions, as these factors represent key drivers that the literature has long acknowledged to be highly heterogeneous within countries (Crescenzi et al. 2014). With this sketch of conceptual model in mind, our empirical

\begin{tabular}{|c|c|c|c|}
\hline \multirow{3}{*}{$\begin{array}{l}\text { Foreign } \\
\text { subsidiaries of } \\
\text { MNCs } \\
\text { - greenfield } \\
\text { projects } \\
\text { - M\&A projects }\end{array}$} & $\begin{array}{r}\text { institutional } \\
\text { factors }\end{array}$ & $\begin{array}{l}\text { - taxation national level } \\
\text { - corruption } \\
\text { - political stability }\end{array}$ & regional level \\
\hline & $\begin{array}{r}\text { traditional } \\
\text { location factors }\end{array}$ & $\begin{array}{l}\text { - national market size } \\
\text { - regional market size } \\
\text { - regional market potential } \\
\text { - regional (un)employment } \\
\text { - sectoral agglomeration } \\
\text { - sectoral productivity } \\
\text { - labour costs }\end{array}$ & \\
\hline & $\begin{array}{l}\text { innovation } \\
\text { capabilities }\end{array}$ & $\begin{array}{l}\text { - human capital } \\
\text { - regional innovative dynamism }\end{array}$ & \\
\hline
\end{tabular}

Fig. 1 Conceptual Model 
exercise aims at operationalising the wide set of relationships discussed above, by accounting for the geographical heterogeneity of the different localisation factors.

\section{Data}

This section describes in detail the data employed in the empirical analysis. A schematic overview of the various indicators and their sources can be found in Appendix Table 7.

\subsection{MNC investment projects}

Data regarding FDI projects is provided by the Amadeus database compiled by Bureau van Dijk. This database consists of company accounts reported to national statistical offices concerning 11 million public and private companies in 41 European countries. This company-level dataset provides the year, the country and region where the company was founded, the ownership structure and the sector of activity. Based on this dataset a selection is made including firms that were newly created in EU countries in the period 2012-2017 with a percentage of assets owned by nonresidents of at least $10 \% .^{1}$ This count data about the number of greenfield investments refers to the quantity of investment projects in a region. A second selection is made in order to include the number of M\&A projects in EU countries. Therefore, all target companies are selected in the Amadeus database and aggregated by their location on NUTS3 level. For both entry modes, the Amadeus database did not provide information about the NUTS3 region of a company for Austria, Greece, Malta and UK. In order to aggregate data on investment projects in these countries, the postcode of each individual investment project is translated into the corresponding NUTS3 region. Data for this transformation is provided by Eurostat (2018). In Table 1 the distribution of investment projects is provided on national level. In total 11,404 greenfield projects and $8387 \mathrm{M} \& \mathrm{~A}$ were carried out by European MNC in the EU countries during the period 2012-2017.

However, sample size requirements of an MLM do not allow to include all EU28 countries in the econometric model. This is especially due to the smallness of some countries and consequently the small number of NUTS3 regions (see Table 1 for a comparison between the official number of NUTS3 regions per country and the number of NUTS3 regions included in this research). Based on the findings of Maas and Hox (2005) about group size requirements in multilevel analyses, countries with an insufficient number of NUTS3 regions $(<10)$ are necessarily excluded from the analyses. These countries are Cyprus, Estonia, Ireland, Luxemburg, Latvia, Malta and Slovakia. Since the dataset covers the post-crisis period from 2012 to 2017, Greece is also excluded from the econometric model, due to the singularity of the recovery process of the Greek economy. Besides the two different entry modes, the

\footnotetext{
1 This selection is based on Capello et al. (2011). However, using the Amadeus database it was not possible to reconduct the data used in the corresponding article even though the selection method seems to be the same. This might be due to different available versions of the Amadeus database.
} 
Table 1 Distribution of investment projects by European MNCs for the period 2012-2018 per country, and the total number of NUTS3 regions included in the dataset

\begin{tabular}{|c|c|c|c|c|}
\hline $\begin{array}{l}\text { Country (italic marked } \\
\text { are excluded from the } \\
\text { analysis) }\end{array}$ & $\begin{array}{l}\text { Number of } \\
\text { greenfield } \\
\text { investments }\end{array}$ & $\begin{array}{l}\text { Number of } \\
\text { M\&A projects }\end{array}$ & $\begin{array}{l}\text { Number of } \\
\text { NUTS3 re- } \\
\text { gions included }\end{array}$ & $\begin{array}{l}\text { Total number } \\
\text { of NUTS3 } \\
\text { regions }\end{array}$ \\
\hline Austria & 241 & 126 & 35 & 35 \\
\hline Belgium & 245 & 139 & 44 & 44 \\
\hline Bulgaria & 79 & 47 & 28 & 28 \\
\hline Croatia & 47 & 36 & 21 & 21 \\
\hline Cyprus & 102 & 67 & 1 & 1 \\
\hline Czech Republic & 327 & 227 & 14 & 14 \\
\hline Denmark & 271 & 146 & 11 & 11 \\
\hline Estonia & 50 & 40 & 5 & 5 \\
\hline Finland & 145 & 73 & 19 & 19 \\
\hline France & 516 & 508 & 101 & 101 \\
\hline Germany & 1034 & 778 & 374 & 402 \\
\hline Greece & 7 & 8 & 47 & 52 \\
\hline Hungary & 61 & 45 & 20 & 20 \\
\hline Ireland & 846 & 692 & 8 & 8 \\
\hline Italy & 645 & 692 & 110 & 110 \\
\hline Latvia & 85 & 58 & 6 & 6 \\
\hline Lithuania & 27 & 25 & 10 & 10 \\
\hline Luxemburg & 418 & 315 & 1 & 1 \\
\hline Malta & 108 & 67 & 2 & 2 \\
\hline Netherlands & 1607 & 801 & 40 & 40 \\
\hline Poland $^{\mathrm{a}}$ & 337 & 229 & 72 & 72 \\
\hline Portugal & 175 & 82 & 23 & 25 \\
\hline Romania & 397 & 256 & 42 & 42 \\
\hline Slovakia & 176 & 85 & 8 & 8 \\
\hline Slovenia & 28 & 36 & 12 & 12 \\
\hline Spain & 445 & 430 & 59 & 59 \\
\hline Sweden & 377 & 231 & 21 & 21 \\
\hline United Kingdom & 2608 & 2148 & 148 & 173 \\
\hline Total & 11,404 & 8387 & 1280 & 1342 \\
\hline
\end{tabular}

Source: Authors' calculations on Amadeus database (columns 1, 2 and 3); Eurostat (2015) for the total number of NUTS3 regions by country (column 4)

aPoland has more than enough observations, but is left out of the analysis due to missing data for some explanatory variables

database also includes information about the core business function of the foreign subsidiaries, based on the NACE Rev.2 classification (Eurostat 2006). Based on this we divide business activities into service and manufacturing, as presented in Appendix Table 8.

The dataset contains 6004 greenfield and 2290M\&A projects for the service sector and 1849 greenfield and 2933 M\&A projects for manufacturing. This is in line with the notion that regarding the growing importance of FDI in the service sector (Capello et al. 2011). 
While our data on MNCs' investment projects allow us to proxy the foreign presence by region within the EU, we cannot account for the intensity of each investment, such as the investment volume or the number of employees working in the foreign firm. We acknowledge this might be a limitation in our study, but for the aim of our paper, which is that of analyzing the location determinants of MNCs, the discrete nature of our data is sufficiently adequate to assess the role of diverse location strategies of MNCs. Furthermore, similar data is use in most prior studies (e.g. Head and Mayer 2004; Defever 2006; Crescenzi et al. 2014).

\subsection{Explanatory variables}

In order to analyse the location decision of MNCs, three sets of explanatory variables are included in the econometric model. In Appendix Table 7 detailed information is provided including the proxy for each variable, the territorial unit, and the source of the data for each variable.

\subsubsection{Traditional location determinants}

The first set of explanatory variables can be summarized as the traditional location determinants since they are "standard" proxies, customary in the literature on the location decision of MNCs. As presented in the previous discussion, the variables included in this set refer to the general market conditions at both national and regional scale.

National and regional market size To start with the market size most studies investigate the effect of the national market size through including the national GDP or the GDP per capita (Schneider and Frey 1985; Wheeler and Mody 1992; Head and Mayer 2004; Botrić and Škuflić 2006; Cleeve 2008; Mohamed and Sidiropoulos 2010). Basile et al. (2008) includes data at the sub-national level with regional GDP per capita and the regional gross value added (GVA), while Crescenzi et al. (2014) include measurements on national and regional level. We follow the literature and include the regional as well as the national market size, measured by the national and the regional GDP per capita in Euro at current price level.

Regional market potential Following Head and Mayer (2004), regional market potential can also be a key element in driving MNC strategies and we capture this with the regional GDP growth rate.

Regional (un)employment by sector As presented in the previous section MNC's investment projects are characterized by a cumulative nature (Head et al. 1995, 1999; Guimaraes et al. 2000). We include a proxy for the number of people working in manufacturing and in the service sector reflects the agglomerative power of both business activities in a region.

Regional labour market With respect to the labour market conditions two proxies are included in the analysis: the unemployment rate of regions and, due to the lack 
of available data on regional labour costs, the average disposable income per person per NUTS2 region is included in the analysis. Since this is not the actual average wage of a person in a NUTS3 region, the assumption is made that data on NUTS2 regions is the same for each corresponding NUTS3 region. However, this means that conclusions are drawn on an aggregation level lower than that of the actual data, which implies that the data is disaggregated. This can cause ecological fallacy, which refers to the incorrect assumption that certain relationships between variables observed at the aggregated level are the same at lower level of aggregation. In particular, NUTS2 level data contain less extreme observations than NUTS3 level data, due to the fact that it is aggregated. Through the use of more precise data, the results would come slightly closer to the reality which implies smaller standard deviations. However, due to the fact that the variable functions as a control variable, this might not cause any methodological issues.

Population density Finally, we incorporate population density as a proxy for urbanisation. This is in line with the argumentation of Bartik (1985) who stresses that population density does not only refer to the level of urbanisation but also to the land costs, since residential and industrial users compete for land.

\subsubsection{Regional innovation capabilities}

The second set of explanatory variables reflects the innovation capabilities of a region in order get more insight into the effect of the local knowledge context on the attraction of foreign MNCs. Existing studies remain scant as there is only a limited number of quantitative analyses that takes this set of explanatory variables into account. Also, the findings in the academic literature show some extent of disagreement, as presented in the theoretical section above. The results of Crescenzi et al. (2014) provide evidence that both $R \& D$ and patent intensity have a positive effect on the location decision of MNCs. We depart from this evidence to study how foreign MNCs respond to local innovation capabilities in designing their location strategies.

Human capital We employ three different measures for the regional innovation environment. We start with human capital as defined by the participation rate in tertiary education (level 5-8) of the age class 25-64 years for NUTS2 regions.

R\&D and patents Subsequently we consider a narrower definition of regional innovative dynamism by including regional $R \& D$ expenditure, measured as percentage of the regional GDP, and the regional patent intensity based on the number of patent applications to the EPO per million inhabitants.

Regional productivity In addition to the three variables above, one further indicator is added to the models that are specified according to the business function of the investment. For investment projects (both entry modes) with primary focus on manufacturing or within the service sector, the Gross Value Added (GVA) is part of the set of the innovation capabilities. Based on the conclusion of Dunning (2013) who states that the regional productivity (output per worker) matters for the 
Table 2 Descriptive statistics of all variables (unstandardized, $N=1204$ )

\begin{tabular}{|c|c|c|c|c|c|c|}
\hline Variable & Description & Mean & St. Dev & Min & Median & $\operatorname{Max}$ \\
\hline \multicolumn{7}{|c|}{ Foreign Direct Investment } \\
\hline$N r \_G I$ & No. Greenfields & 7.90 & 40.58 & 0 & 1 & 960 \\
\hline$N r \_M A$ & No. M\&As & 6.60 & 18.40 & 0 & 2 & 244 \\
\hline GI_MANU & $\begin{array}{l}\text { No. Greenfields } \\
\text { (manufacturing) }\end{array}$ & 1.42 & 4.13 & 0 & 0 & 59 \\
\hline GI_SERVICE & $\begin{array}{l}\text { No. Greenfields } \\
\text { (services) }\end{array}$ & 3.97 & 29.25 & 0 & 0 & 846 \\
\hline$M A \_M A N U$ & $\begin{array}{l}\text { No. M\&As (manu- } \\
\text { facturing) }\end{array}$ & 2.33 & 4.54 & 0 & 1 & 66 \\
\hline MA_SERVICE & $\begin{array}{l}\text { No. M\&As (ser- } \\
\text { vices) }\end{array}$ & 1.79 & 6.79 & 0 & 0 & 119 \\
\hline \multicolumn{7}{|c|}{ Traditional determinants } \\
\hline$n G D P \_P C$ & $\begin{array}{l}\text { National GDP per } \\
\text { capita }\end{array}$ & $30,857.31$ & $10,975.95$ & 6300 & 37,300 & 47,800 \\
\hline$l G D P \_P C$ & $\begin{array}{l}\text { Regional GDP per } \\
\text { capita }\end{array}$ & $28,506.49$ & $22,073.83$ & 3015.90 & $27,393.60$ & $475,495.10$ \\
\hline lGDP_GR & $\begin{array}{l}\text { Regional GDP } \\
\text { growth }\end{array}$ & 21.03 & 181.03 & -943.00 & 3.92 & 977.00 \\
\hline lGVA_ALL & GVA (all) & 9706.68 & $15,502.29$ & 170.90 & 5491.78 & $185,755.80$ \\
\hline IEMPL_ALL & Employment (all) & 175.09 & 219.30 & 3.70 & 120.99 & 3079.90 \\
\hline rINC & Disposable income & $16,599.50$ & 4573.24 & 5400 & 17,300 & 39,000 \\
\hline IPOP_DENS & Population density & 620.22 & 1507.11 & 1.90 & 155.20 & $21,242.80$ \\
\hline \multicolumn{7}{|c|}{ Innovation capabilities } \\
\hline rRNDEX & R\&D expenditure & 1.80 & 1.34 & 0.06 & 1.49 & 8.80 \\
\hline$r E D U$ & $\begin{array}{l}\text { Tertiary enrolment } \\
\text { rate }\end{array}$ & 29.33 & 9.01 & 11.50 & 27.90 & 74.80 \\
\hline$I P A T_{-} A P$ & $\begin{array}{l}\text { No. Patent applica- } \\
\text { tions }\end{array}$ & 113.46 & 119.41 & 0.23 & 81.33 & 590.06 \\
\hline $\begin{array}{l}r G V A_{-} \\
M A N U_{-} P C\end{array}$ & $\begin{array}{l}\text { Productivity (manu- } \\
\text { facturing) }\end{array}$ & 0.01 & 0.004 & 0.001 & 0.01 & 0.02 \\
\hline $\begin{array}{l}r G V A_{-} \\
\text {SERVICE_PC }\end{array}$ & $\begin{array}{l}\text { Productivity (ser- } \\
\text { vices) }\end{array}$ & 0.01 & 0.01 & 0.001 & 0.01 & 0.12 \\
\hline \multicolumn{7}{|c|}{ Institutional factors } \\
\hline$n P S T$ & Political stability & 0.56 & 0.29 & -0.06 & 0.51 & 1.02 \\
\hline$n S C I T$ & $\begin{array}{l}\text { Statutory corporate } \\
\text { income tax }\end{array}$ & 26.03 & 6.90 & 10.00 & 25.00 & 35.40 \\
\hline$n E A T R$ & $\begin{array}{l}\text { Effective corporate } \\
\text { tax rate }\end{array}$ & 24.22 & 6.04 & 9.00 & 23.50 & 33.40 \\
\hline$n C O R$ & Corruption & 70.56 & 13.38 & 43 & 81 & 88 \\
\hline
\end{tabular}

Variables prefixed with $n$ are measured at the national level, with $r$ at the NUTS 2 level, and with I at the NUTS 3 level. Produced using Stargazer (Hlavac 2018) 
attraction of foreign direct investments by MNCs, the GVA per worker is included in the relevant analyses. As for the number of investment projects, the GVA value is specified according to the NACE Rev.2 classification (see Table 2).

\subsubsection{Institutional factors}

As discussed in the conceptual section, an increasing number of studies account for the role of the institutional environment in shaping MNCs' location decisions.

Corruption Most of these researches show that government corruption has a negative effect on the attractiveness of a location (Cleeve 2008). However, evidence is not unambiguous as other studies fail to detect any significant relationship between government corruption and inward FDI (Wijeweera and Dollery 2009). We include a corruption perception index $(n C O R)$ as an explanatory variable to understand this fundamental aspect of government quality in attracting foreign MNCs. Higher values indicate a higher perceived level of corruption. However, this variable is closely correlated with one of our taxation variables, and is therefore omitted from our main tables.

Taxation A second crucial dimension emerging from the literature regards the level of corporate taxation (Devereux and Griffith 1998a). Nevertheless, the discussion of the studies of Bellak and Leibrecht (2009) and of Buettner and Ruf (2007) show that there is to some inconsistency in the academic literature about the effect of different measurements for corporate taxation. Due to the mixed evidence this study includes two well-known measures of taxation, namely the statutory corporate income tax and the effective average tax rate (EATR) in order to contribute to the academic debate and to fill this knowledge gap. Data for both variables is provided by the Centre for European Economic Research (Spengel et al. 2017).

Political stability Finally, political stability is included in this research as a location determinant of MNCs' investment projects. Based on several investor surveys, Asiedu (2006) constructs a variable that measures the rule of law, using data derived from the International Country Risk Guide. Biswas (2002) measures political stability through the duration of a regime by applying the definition of Clague et al. (1994) who state that for a democracy the duration of a regime refers to the number of consecutive years that the country has been a democracy, while for an autocracy, duration refers to the number of years that a particular autocrat has been in power. Cleeve (2008) uses indices for political freedom and civil liberty and combines them in order to measure political stability. Since all different measurements show the same effect on the location decision of MNCs, this research introduces as new proxy for political stability. By employing data from the World Bank (2016) we use the indicators for political stability and absence of violence/terrorism as institutional measures. 


\subsection{Methodology}

We investigate the location determinants of MNCs by means of a quantitative approach. Our dependent variable is the location of MNCs' investment projects. We are able to split this variable according to the entry mode of the investment, i.e. greenfield investments or M\&A. Both are measured by taking into account the number of projects per NUTS3 region. An overview of the number of investment projects by country can be found in Table 1 . Our data also allows to differentiate between manufacturing and service activities (see Appendix Table 8), thus permitting an analysis by sector and entry mode. The independent variables refer to three sets of factors, namely traditional drivers, innovation capabilities and institutional elements. Because this data includes different levels of aggregation (NUTS 0, NUTS 2 and NUTS 3) the observations are not independent, and we apply multilevel modelling to take this heteroscedasticity into account (Hox et al. 2017).

Due to the fact that the model contains different sets of variables and due the hierarchical structure of the data, the analysis is carried out stepwise for each measurement of the independent variable through the gradual inclusion of the predictors. Before running the empirical analysis, two important data transformations deserve special attention. First, in order to prevent a violation of the assumptions of an MLM, the dependent variable is transformed by applying the logarithm to base 10. This is done for all six measurements of the dependent variable, respectively the number of foreign direct investments by entry mode and economic activity. Due to the fact that the $\log (0)_{10}$ is undefinable, we increase each value by one, to anticipate possible errors in the dataset - a well-known adjustment in the trade literature (Linders and Groot 2006). Secondly, we standardize all independent variables. Descriptive statistics before standardization are presented in Table $2 .^{2}$

Our formula to be estimated in the main models is given in Eq. 1, where variables prefixed with $n$ are measured at the national level, with $r$ at the NUTS 2 level, and with $l$ (for 'local') at the NUTS 3 level. ${ }^{3}$ Equation 1 is a random-intercept model; $j$ represents the upper, national level, for which separate fixed effects are measured, and their variance is reported in the tables. We also estimate a random slope model, where the coefficient for $I E M P L \_A L L$ is allowed to vary by country; this model is presented in Eq. 2. ${ }^{4}$ For further details, we refer to Sect. 4.1, below.

$$
\begin{aligned}
& \log G I_{i j} \text { or } \log M A_{i j}=\beta_{0}+\beta_{j 0}+\beta_{1} n G D P P_{-} P C_{j}+\beta_{2} l G D P \_P C \\
& +\beta_{3} l G D P \_G R+\beta_{4} l E M P L_{-} A L L+\beta_{5} r I N C+\beta_{6} l P O P \_D E N S+\beta_{7} r E D U \\
& +\beta_{8} l P A T_{-} A P+\beta_{9} r R N D E X+\beta_{10} n P S T_{j}+\beta_{11} n E A T R_{j} \\
& \text { or } \beta_{11} n S C I T_{j}+\beta_{j 0}+\epsilon
\end{aligned}
$$

\footnotetext{
2 Q-Q plots as well as histograms of residuals are available upon request.

3 Since the regional and local levels are not explicitly included in our multilevel model, we do not apply suffixes to these variables.

${ }^{4}$ In Table 6, one random slope model is presented where not $l E M P L \_A L L$ but $l G D P \_P C$ is allowed to vary.
} 


$$
\begin{aligned}
& \log G I_{i j} \text { or } \log M A_{i j}=\beta_{0}+\beta_{1} n G D P P_{-} P C_{j}+\beta_{2} l G D P \_P C+\beta_{3} l G D P \_G R \\
& +\beta_{4} l E M P L_{-} A L L+\beta_{j 4} l E M P L_{-} A L L+\beta_{5} r I N C+\beta_{6} l P O P \_D E N S \\
& +\beta_{7} r E D U+\beta_{8} l P A T_{-} A P+\beta_{9} r R N D E X+\beta_{10} n P S T_{j}+\beta_{11} n E A T R_{j} \\
& \text { or } \beta_{11} n S C I T_{j}+\beta_{j 0}+\epsilon
\end{aligned}
$$

\subsection{Endogeneity and other robustness checks}

Although foreign direct investment is attracted to places with a large degree of economic success, it also contributes directly to such success-in other words, there is a risk of reverse causality in the model. To counter this, we rerun our main analyses with time-lagged variables, taking 2014 data from Eurostat for regional GDP per capita, regional R\&D expenditure and regional disposable income.

There is also a risk capital cities form outliers, impacting our results to a disproportionate degree. Particularly Central and Eastern European cities stand out markedly from the rest of their countries (Gorzelak and Smętkowski 2010). One could argue, however, that these are not outliers in the traditional sense; they form part and parcel of the actual world, and strong non-linear contrasts in the data will simply increase the standard errors in our estimates. Of course, the analysis without capital regions does form a better basis for policy advice to non-capital regions.

Finally, our variable disposable income $(r I N C)$ is not the actual average wage. We will therefore also test whether omitting this variable changes the results.

\section{Results}

In this section, the results of the multilevel models are presented. As described above, each model is built stepwise, starting with an intercept-only model which is followed by a random intercept model. Then, the model is extended by including additional sets of explanatory variables. Finally, a random slope model is reported, in case it fits the data significantly better than the complete random intercept model.

\subsection{The regional attraction of greenfield investments}

The impact of different location determinants on the regional concentration of greenfield investments is presented in Table 3. In the first column the base model is provided, including only the intercept. In the second model the intercept is allowed to vary across the 17 countries that are included in the analyses. The intra-class correlation in this model is 0.029 indicating that $2.9 \%$ of the variance is explained on country level. Since this model does not contain any explanatory variables, the residual variance $\left(\sigma_{e}^{2}\right)$ represents unexplained error variance.

The traditional location determinants are included in the third column. Starting with the national GDP per capita the estimated results show a negative and weakly significant impact on the number of greenfield investments in a region, suggesting 







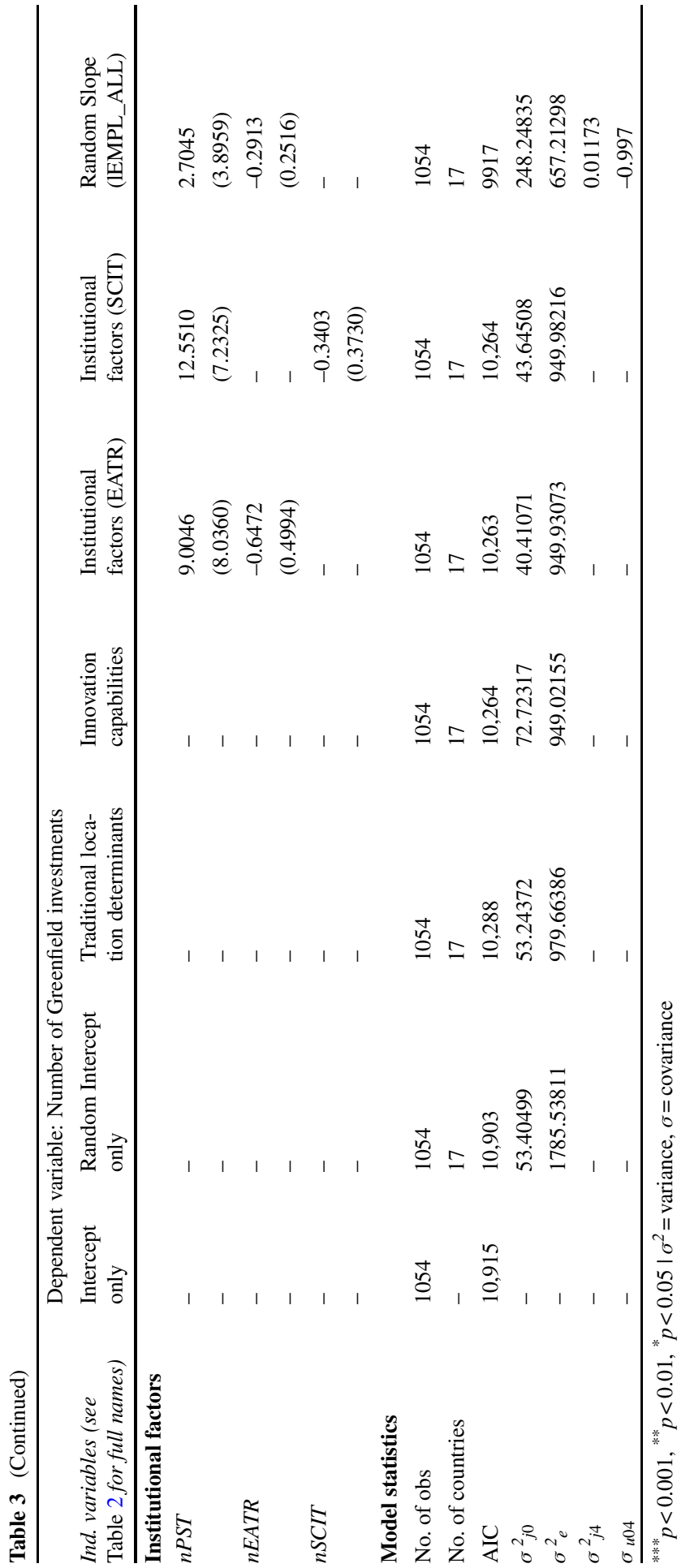


that MNCs may prefer countries with relatively less large markets within Europe when it comes to setting up greenfield activities. All other traditional location determinants show the expected positive effect on the regional attraction of greenfield investments, or an effect that is statistically insignificant. The regional market size, proxied by the regional GDP per capita, shows highly significant results, indicating that market access considerations at the regional level have, instead, an important impact on greenfield location decisions of MNCs (Head and Mayer 2004). The results for the growth rate of the regional GDP show that there is no statistically significant effect on the number of greenfield investments in a region. This means that only the actual regional market size plays a role in determining the location of a greenfield investment. With respect to the conditions of local labour markets, larger employment figures, indicating a more dynamic and well-functioning context for workers, are positively correlated with the number of inward greenfield FDI, in line with existing evidence (Disdier and Mayer 2004). As far as the regional income conditions are concerned, we cannot detect any significant relationship between MNCs greenfield activities and local average disposable income. Similarly, the role of agglomeration externalities in attracting MNCs' greenfield FDI is not relevant in our results.

In the column 4 of Table 3, we enter regional innovation capabilities into the regression specification. A preliminary observation is that the coefficients on the traditional determinants of greenfield FDI remain similar to column 3, thus reassuring us on the stability of our estimates. In this specification, only the educational attainment of the regional population exhibit a significant and positive effect on the number of greenfield investments, among the regional set of knowledge indicators. Therefore, after controlling for other factors, MNCs more systematically invest into local economies with a relatively high participation rate in tertiary education, in line with existing evidence that more sophisticated skills and know-how are key drivers of corporate strategies, especially when it comes to strategic asset seeking investment (e.g. Schneider and Frey 1985; Cleeve 2008; Ascani et al. 2016). Surprisingly, however, the technological endowment of host locations as well as their R\&D expenditure are negatively associated with greenfield FDI. While counterintuitive, this may suggest that, on average, MNCs' greenfield activities are not primarily oriented towards the development of new knowledge and, consequently, tend to avoid regional technological hubs, which plausibly represent more expensive locations.

This contradicts the previous findings that these aspects constitute important drivers of firm location decisions (Crescenzi et al. 2014). The exploration of the model fit shows that the AIC has decreased, which means that the quality of the model as a whole has increased in comparison to the previous model where only traditional location determinants are included.

After including the institutional factors (columns 5 and 6), the model fit also does not show any significant improvement. This is due to the fact the most variables included in this set of predictors do not have a statistically significant effect on the number of greenfield investments in a region. Hence, we do not detect in our data the results of De Mooij and Ederveen (2006) that corporate taxation has a negative impact on the attraction of foreign direct investment. With respect to the effect of 
political stability on the number of greenfield investments, the results indicate that there is no statistically significant relation. ${ }^{5}$

In the last column of Table 3 the results of the random slope model are presented. This model allows the slope of the relationship between the number of employees and the number of greenfield investments in a region to vary across 17 countries (NUTS 0 regions). The decision to include the number of employees as the random slope variable is due to the better model fit compared to the random slope models that allow other predictors to vary across NUTS 0 regions. The random slope model fits the data significantly better than the other multilevel models. This means that the effect of the number of employees on the number of greenfield investments differs not only in terms of the average number of greenfield investments (intercept) but also in the intensity of the relationship (slope) across countries: in some countries, the relationship between regions with strong employment concentrations and greenfield investments - in other words, agglomeration effects—are stronger than in others.

\subsection{Greenfield investments in manufacturing and in the service sector}

In Table 4 we evaluate whether the location determinants of foreign MNCs differ according to sectors, by considering greenfield investments in manufacturing and the service sector. For greenfield FDI in manufacturing the national GDP per capita has a significant negative effect, thus driving the aggregate results shown in Table 3. However, the results on the regional GDP per capita suggest that the market conditions of the specific region of the greenfield investment are important for the MNC strategy. Taken together, we interpret these results as an indication that MNCs prefer regions with good market opportunities in countries with a lower GDP per capita for their greenfield investments in manufacturing activities. These could be, for instance, the case of the most developed regions in the EU periphery, which are known to be particularly attractive for foreign activities, especially in manufacturing. This interpretation is supported by a number of empirical findings in Petrakos and Economou (2002), Traistaru et al. (2003), who highlight the process of relocation of manufacturing activity within the EU has benefitted capital cities and core regions in the EU periphery. For greenfield investments in the service sector, instead, we only detect a positive and statistically significant coefficient on the regional GDP per capita measure, thus, indicating that greenfield investments in this sector tend to locate in regions with larger local market, regardless of the national size of the economy. Based on this finding, it can be stated that MNCs tend to locate their greenfield investments in the service sector in core regions across the EU, while greenfield investments in manufacturing are preferably located in well-developed regions within relatively less advanced countries. With respect to the labour market conditions, greenfield investments in both business activities show statistically

\footnotetext{
5 A model including the CPI instead of the corporate income tax is provided in Appendix Table 9. The results show a statistically slightly significant negative effect on the number of greenfield investments, suggesting investments are less prevalent in areas with a higher (perceived) corruption levels. The estimated coefficients for other variables are barely impacted, but since $n G D P$ is very correlated to the corruption variable, it had to be dropped from the analysis to prevent multicollinearity, making those results less dependable.
} 


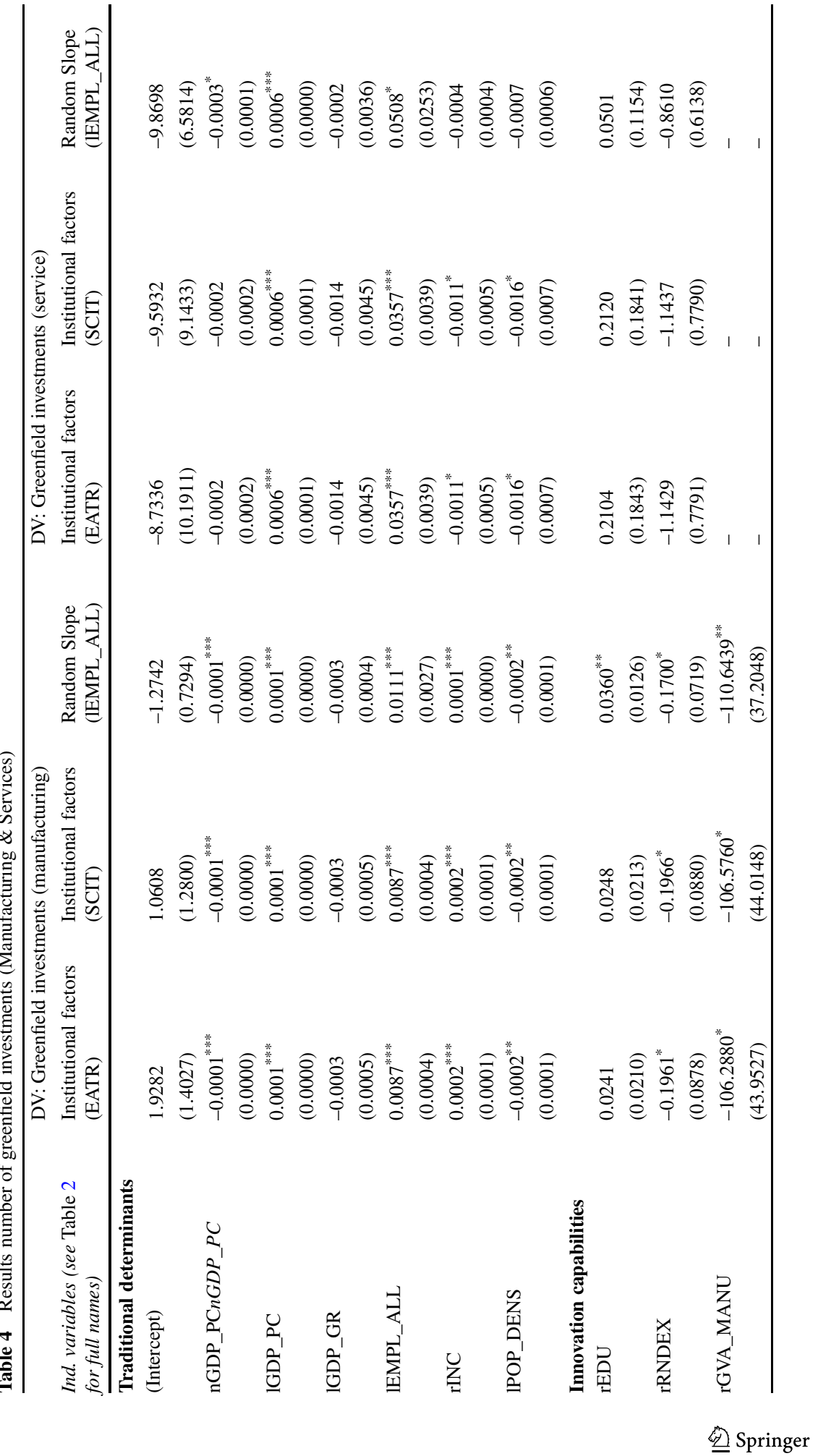




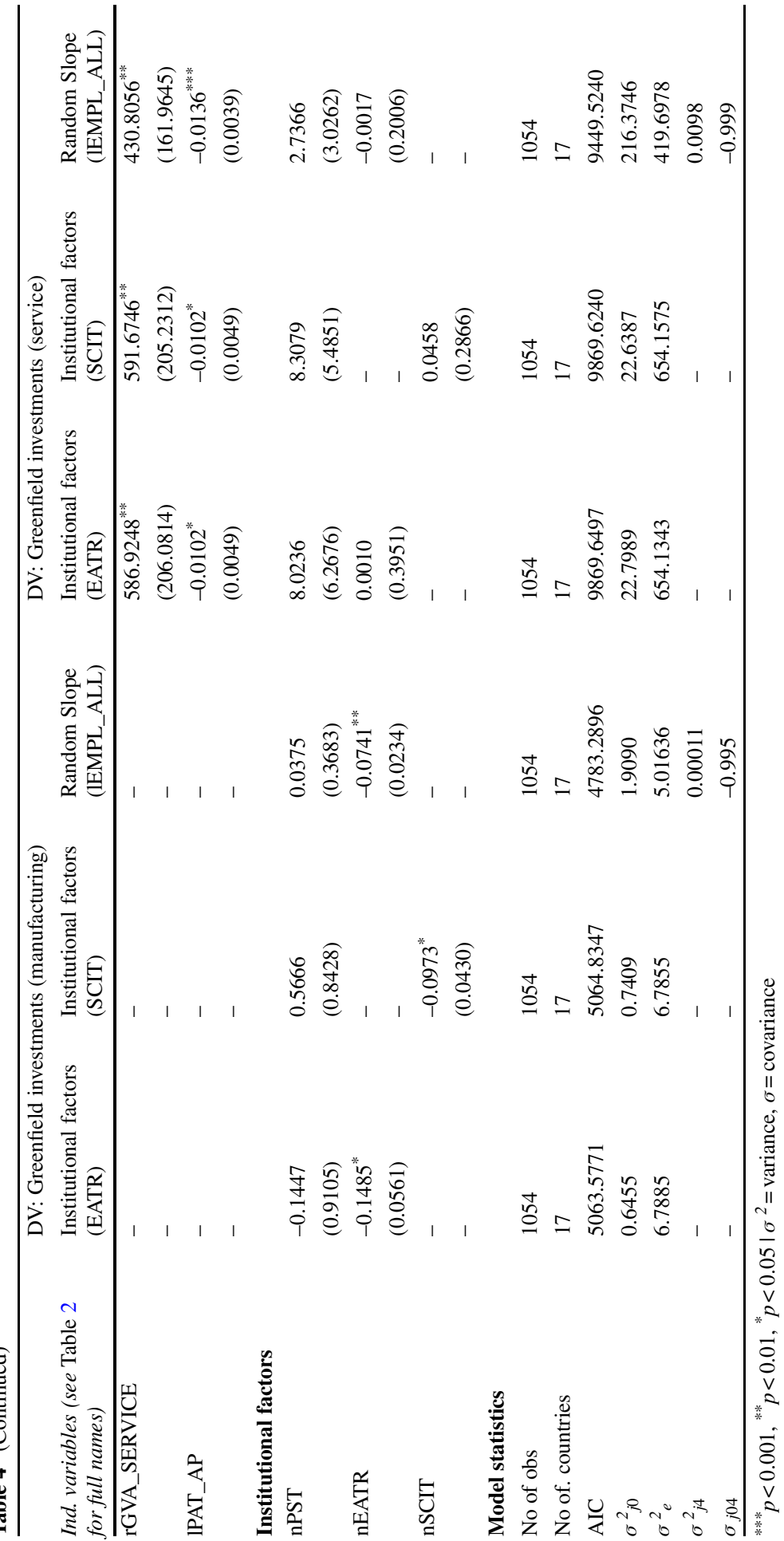


significant positive results for the effect of regional employment, indicating that MNCs prefer those regions where the employment rate is relatively high. However, this findings hold across specification for the manufacturing regressions, while it tends to lose statistical relevance in the case of services. Overall, we interpret this as evidence that MNCs are attracted to locations with well-functioning local labour markets, especially as far as manufacturing operations are concerned. Another important difference emerging from the sectoral analysis regard the role of paid wages in a region, proxied by disposable income. In fact, while MNCs setting up foreign greenfield activities in manufacturing are pulled to locations with higher wages, thus plausibly privileging more productive labour (c.f. Guimaraes et al. 2000; Defever 2006), in the case of services we find (weak) evidence that MNCs adopt a more efficiency-seeking strategy by locating in places with lower salaries (Dunning and Lundan 2008).

Contrarily to expectations, investment projects in both manufacturing and services tend to be overall located in regions where the population density is lower, referring to less urbanised regions that are associated with lower land costs, fundamentally in line, once again, with a type of efficiency seeking rationale.

With respect to the innovation capabilities of regions some differences emerge depending on the main sector of economic activity of the MNC investment. The educational attainment of the local labour force has a significant and positive effect only in one specification regarding manufacturing activity (i.e. model with random slope), while it remains insignificant in the other regressions. Similarly, R\&D expenditure is significant and negative only for manufacturing investment. These set of results, on average, signal that the MNCs in our data are not systematically undertaking strategic asset-seeking FDI, and therefore the knowledge-related feature of the regional economy do not matter for their greenfield activities.

Institutional factors are also included in this empirical exercise. For greenfield investments of both types of business activities the results suggest that this set of explanatory factors does not influence the number of investment projects, with the exception of taxation levels, that in the case of manufacturing activity represent a clear detrimental factor that discourages MNCs' investment, in line the extant evidence (Voget 2011).

It is worth noting that, gain, the random slope models, estimated for greenfield investments in both business activities, significantly improves the model fit.

\subsection{The regional attraction of $M \& A$ projects}

Given their inherently different nature, it is possible that the MNCs' strategies governing greenfield FDI differ from the location decisions behind M\&A projects (Bertrand et al. 2007). Therefore, we perform the same empirical analysis for the case of M\&A. Table 5, nevertheless, shows that the location determinants of MNCs activity do not differ much across entry modes. In fact, our results suggest that M\&A follow a similar pattern to greenfield FDI, suggesting that the choice of the entry mode of foreign MNCs does not strongly depend on the attributes of the locations available. It is plausible that this choice instead is more dependent on individual company features, as indicated by several studies (Nocke and Yeaple 
Table 5 Results for the number of M\&A projects

\begin{tabular}{|c|c|c|c|c|c|}
\hline \multicolumn{6}{|c|}{ DV: Number of M\&A projects } \\
\hline $\begin{array}{l}\text { Ind. variables (see } \\
\text { Table } 2 \text { for full } \\
\text { names) }\end{array}$ & $\begin{array}{l}\text { Traditional } \\
\text { determi- } \\
\text { nants }\end{array}$ & $\begin{array}{l}\text { Innovation } \\
\text { capabilities }\end{array}$ & $\begin{array}{l}\text { Institutional } \\
\text { factors } \\
\text { (EATR) }\end{array}$ & $\begin{array}{l}\text { Institutional } \\
\text { factors } \\
\text { (SCIT) }\end{array}$ & $\begin{array}{l}\text { Random Slope } \\
\text { (IEMPL_ALL) }\end{array}$ \\
\hline \multicolumn{6}{|c|}{ Traditional determinants } \\
\hline \multirow[t]{2}{*}{ (Intercept) } & $-9.8356^{* * *}$ & $-12.5347^{* * *}$ & $-9.3624^{*}$ & $-11.3857^{* * *}$ & -6.3912 \\
\hline & $(2.9229)$ & $(2.5951)$ & $(3.6328)$ & $(3.3642)$ & $(4.0533)$ \\
\hline \multirow[t]{2}{*}{ nGDP_PCnGDP_PC } & $-0.0002^{*}$ & $-0.0003^{* *}$ & $-0.0002^{* *}$ & $-0.0003^{* *}$ & $-0.0002^{*}$ \\
\hline & $(0.0001)$ & $(0.0001)$ & $(0.0001)$ & $(0.0001)$ & $(0.0001)$ \\
\hline \multirow[t]{2}{*}{ 1GDP_PC } & $0.0004^{* * *}$ & $0.0004^{* * *}$ & $0.0004^{* * *}$ & $0.0004^{* * *}$ & $0.0004^{* * *}$ \\
\hline & $(0.0000)$ & $(0.0000)$ & $(0.0000)$ & $(0.0000)$ & $(0.0000)$ \\
\hline \multirow[t]{2}{*}{ 1GDP_GR } & -0.0013 & -0.0013 & -0.0010 & -0.0010 & -0.0010 \\
\hline & $(0.0016)$ & $(0.0016)$ & $(0.0016)$ & $(0.0016)$ & $(0.0013)$ \\
\hline \multirow[t]{2}{*}{ 1EMPL_ALL } & $0.0549^{* * *}$ & $0.0549^{* * *}$ & $0.0549^{* * *}$ & $0.0549^{* * *}$ & $0.0591^{* * *}$ \\
\hline & $(0.0014)$ & $(0.0014)$ & $(0.0014)$ & $(0.0014)$ & $(0.0091)$ \\
\hline \multirow[t]{2}{*}{ rINC } & $0.0003^{*}$ & 0.0002 & 0.0002 & 0.0002 & 0.0001 \\
\hline & $(0.0001)$ & $(0.0002)$ & $(0.0001)$ & $(0.0001)$ & $(0.0001)$ \\
\hline \multirow[t]{2}{*}{ 1POP_DENS } & -0.0003 & $-0.0007^{* *}$ & $-0.0007^{* *}$ & $-0.0007^{* *}$ & 0.0001 \\
\hline & $(0.0002)$ & $(0.0002)$ & $(0.0002)$ & $(0.0002)$ & $(0.0002)$ \\
\hline \multicolumn{6}{|l|}{ Innovation capabilities } \\
\hline \multirow[t]{2}{*}{ rEDU } & - & $0.2762^{* * * *}$ & $0.2797^{* * *}$ & $0.2805^{* * *}$ & $0.1368^{*}$ \\
\hline & - & $(0.0710)$ & $(0.0623)$ & $(0.0637)$ & $(0.0563)$ \\
\hline \multirow[t]{2}{*}{ IPAT_AP } & - & $-0.0064^{* * *}$ & $-0.0066^{* * *}$ & $-0.0066^{* * *}$ & $-0.0064^{* * *}$ \\
\hline & - & $(0.0017)$ & $(0.0017)$ & $(0.0017)$ & $(0.0013)$ \\
\hline \multirow[t]{2}{*}{ rRNDEX } & - & $-0.6104^{*}$ & $-0.6474^{*}$ & $-0.6533^{*}$ & -0.3070 \\
\hline & - & $(0.2746)$ & $(0.2706)$ & $(0.2714)$ & $(0.2201)$ \\
\hline \multicolumn{6}{|l|}{ Institutional factors } \\
\hline \multirow[t]{2}{*}{ nPST } & - & - & 2.5951 & 4.3669 & 0.1788 \\
\hline & - & - & $(2.2759)$ & $(2.1150)$ & $(2.5332)$ \\
\hline \multirow[t]{2}{*}{ nEATR } & - & - & $-0.3601^{*}$ & - & -0.3027 \\
\hline & - & - & $(0.1415)$ & - & $(0.1553)$ \\
\hline \multirow[t]{2}{*}{ nSCIT } & - & - & - & $-0.2380^{*}$ & - \\
\hline & - & - & - & $(0.1090)$ & - \\
\hline \multicolumn{6}{|l|}{ Model statistics } \\
\hline Num. obs & 1054 & 1054 & 1054 & 1054 & 1054 \\
\hline AIC & 7677.5390 & 7650.7115 & 7643.5836 & 7644.7092 & 7230.2227 \\
\hline Num. countries & 17 & 17 & 17 & 17 & 17 \\
\hline$\sigma^{2}{ }_{j 0}$ & 14.8950 & 9.5364 & 3.1765 & 3.7811 & 19.839 \\
\hline$\sigma^{2}{ }_{e}$ & 81.168 & 79.1046 & 79.1998 & 79.1568 & 50.045 \\
\hline$\sigma_{j 4}^{2}$ & - & - & - & - & 0.0013 \\
\hline$\sigma_{j 04}$ & - & - & - & - & -0.875 \\
\hline
\end{tabular}


2007; Guadalupe et al. 2012). Overall, the pattern of localisation that we detect for the case of M\&As reflect corporate strategies oriented towards the access of localised markets of core regions within countries that are economically peripheral within the EU, as indicated by the persistent positive sign on regional GDP per capita and the negative sign on the national GDP per capita variable. Invariably, a well-functioning the local labour market and the presence of a suitable workforce represent a key pull factor for investment (Crescenzi et al. 2014), while, similar to the above results, we cannot find univocal evidence that more developed regional innovation capabilities constitute a positive determinant of M\&As. In fact, with the exception of an educated workforce, that is still positively evaluated by foreign capital investors, the regional stock of knowledge captured by patents as well as the local expenditure in $R \& D$ seem to be detrimental for the attraction of foreign investment. This could be the case if, on average, the rationale of most M\&As in our dataset is market-seeking or efficiency-seeking, rather than directed towards the access of specific capabilities or knowledge bases (Guadalupe et al. 2012; Ascani 2018). In this sense, foreign MNCs may prefer less expensive locations, where it is plausible that the frequency of activities oriented towards the generation of new technologies are far from being relevant. The efficiency-seeking character of these investment decisions is also supported by the negative, yet weak, coefficients on the variables capturing the taxation level of alternative locations. This also represents the main difference with the case of aggregate greenfield activities examined above, where the relationship between the location choice and taxation was not statistically significant. Since M\&A projects frequently have an efficiency seeking motive (Neary 2004), these findings are in line with the expectation that MNCs tend to cherry-pick locations with cost-advantages.

Finally, a random slope variable is introduced in the equation. The results are presented in the last column of Table 5. The AIC has decreased substantially, which means that the model fits the data better compared to the random intercept models.

\subsection{M\&A projects in manufacturing and in the service sector}

In Table 6 we present the results for the M\&A location choice analysis split by sector. While the general trends identified above are also reflected in this set of results, some differences emerge across sectors of economic activity. Starting with the similarities, for M\&As in both manufacturing and service the national market size weakly suggest that MNCs locate in countries that exhibit relatively lower GDP, in line with the aggregate results, thus potentially indicating that most corporate activities move to the periphery of the EU. On the contrary, for both business activities the regional GDP per capita has a significant positive effect, corroborating the existing evidence that the regional market size is highly valued by MNCs for their M\&A projects. This is in line with the results of Brakman et al. (2007) who have concluded that especially horizontal investments frequently have a market-seeking motive. Also, MNCs favour locations with a higher employment rate since it reflects a larger endowment of available labour force (Disdier and Mayer 2004). Regarding the differences across sectors, instead, we find mixed evidence on the average disposable income as a proxy for the wages paid in a region, as this is clearly negative in the case of services while 







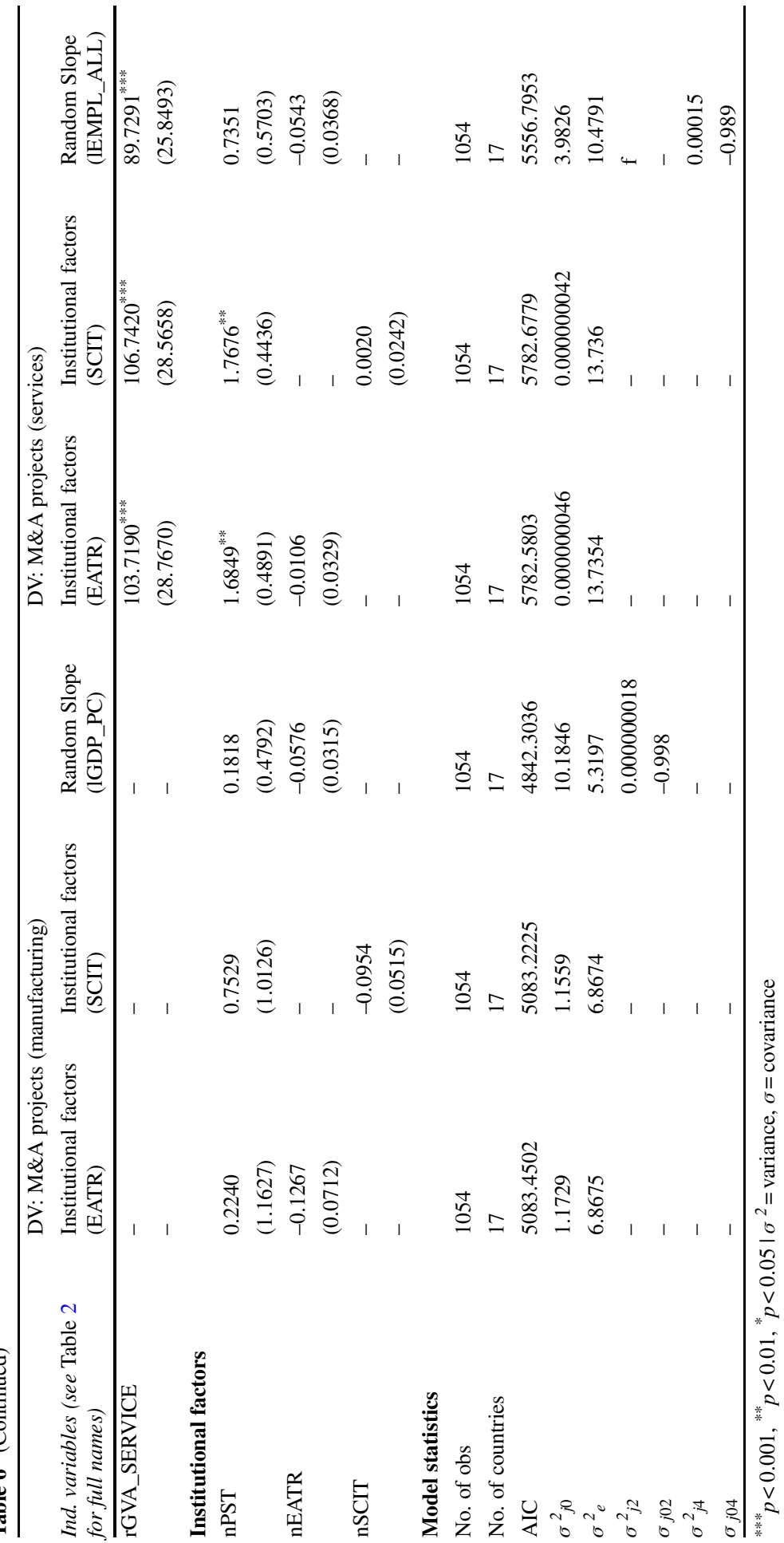


ambiguous results emerge for the case of manufacturing. Nevertheless, considering that the random slope specification in column 3 delivers better estimates according to the AIC, we tend to consider this as our preferred specification. Therefore, these set of results support, again, the efficiency-seeking nature of most MNCs investment by $M \& A s$, in line with the idea that the cost-reducing rationale is a strong element in the corporate strategies of these actors (Gereffi and Korzeniewicz 1994). Our results also suggest that existence of heterogeneous preferences of MNCs regarding urban agglomerations, as the population density variable exhibits a negative and statistically significant coefficient in the case of manufacturing, signalling that these activities tend to locate in less urbanised areas where the land costs are lower, while it remains non-significant for services.

With respect to the effect of regional innovation capabilities, the results of the random slope model suggest that, controlling for a varying effect of the regional market size across countries, the educational attainment and the sectoral GVA have a statistically significant effect on the number of investment projects in manufacturing, although the statistical relevance of the educational variable remains weak. For services, instead, while the sector GVA is also an important determinant of location choice, the educational level of the regional population remains insignificant in the random slope model, signalling that tertiary activities may not be dependent on this type of factor. Potentially, these are not high value added service activities for which specific skills are requested. Regarding the other variables, results remain similar to those presented above in the aggregate analysis. Overall, we find evidence that M\&A activities also respond to a marked market access rationale, especially at the regional level, and that also efficiency-seeking motives play a substantial role in shaping the patterns of MNCs' investment, especially as far as manufacturing activities are concerned. This is in line with the evidence that the location of European manufacturing has experiences a long shift towards locations offering a stronger cost-advantage (Traistaru et al. 2003).

\section{Conclusion}

In this study we explored the location determinants of European MNCs' investment projects in the countries of the EU by means of a quantitative multilevel analysis focusing on both regional and national pull factors, thus accounting for the hierarchical structure of the data and business dynamics. In so doing, we incorporated and built on the main findings of the previous literature, by accounting for three main sets of locational factors, namely: traditional drivers of FDI, knowledge-based regional factors and the features of the institutional context. Moreover, in order to provide a detailed analysis, FDI projects are also distinguished based on their entry mode (i.e. greenfield investments and M\&A). In order to test the sensitivity of MNCs choices to sectoral dynamics we also considered the changing composition of FDI in Europe by differentiating between manufacturing and service activities.

We identify a plethora of original results that only partially reflect existing empirical evidence and to some extent they expand the understanding of MNCs location strategies in new directions. The main results suggest that there are no major dif- 
ferences in the location determinants of greenfield FDI and M\&A projects within Europe, as both types of foreign investment seems to be market-seeking and efficiency-seeking in nature. Contrary to the findings of Basile (2004) who concludes that the location determinants of FDI differ according to the entry mode and to the hypothesis of Bertrand et al. (2007) who state that it is not reasonable to assume that the location determinants of greenfield investments and M\&As are identical, our results indicate the differences in the role of location determinants are minimal. More specifically, with respect to the traditional location determinants, MNCs seem to value a relatively larger regional market size, indicating that FDI is mostly attracted to economically "core" regions (Crescenzi et al. 2014). This is also supported by the results with respect to the labour market conditions since FDI projects are concentrated in regions where the employment rate and, consequently, the functioning of the local labour market is relatively efficient. However, the level of urbanisation, associated with land costs tends to discourage foreign MNCs, especially in manufacturing activities, as these type of activities might not necessarily need urbanisation externalities to thrive.

Regarding regional innovation capabilities, the results show that MNCs systematically prefer locations endowed with a relatively highly educated population for their international activities, as this is the case of greenfield FDI in manufacturing and M\&As in tertiary activities mainly. Nonetheless, the more technologically-oriented features of regional economies, such as their patent stock and their expenditure in $\mathrm{R} \& \mathrm{D}$, are negatively correlated with foreign investment. This may support a view of MNCs' internationalisation in our data oriented towards a cost-reducing approach, whereby the most technologically advanced regions are not affordable locations for most foreign investment activities. Considering also that the main and most stable result of the analysis indicates that market access considerations are important, we can rule out that the search for novel knowledge capabilities guide the location behaviour of MNCs in our sample.

As far as the institutional dimension is concerned, the analysis provides some evidence that the effective average tax rate has a negative impact on the number of investment projects, in line with the cost reducing motivation of foreign direct investment projects. Political stability and government corruption both seem not to determine the location of MNCs within Europe, probably due to the low variation of these institutional features within the EU.

Considering these articulated results, policy making aimed at attracting FDI, in the form of both greenfield projects and M\&A, should primarily reinforce the regional economic system in terms of market opportunities, quality of the local labour force and functioning of the regional labour markets, as this emerge as the crucial spatial scale for successfully attracting MNCs. Importantly, this focus on the features of the local economy should lead to the attraction of specific inward FDI projects that can match the regional economic structure in terms of competences and interfirm linkages, in order to generate additional local economic effects, as suggested by recent empirical evidence (Ascani et al. 2019). It is also fundamental to consider that the advantages of core European regions over disadvantaged locations could increase as a result of the stronger capacity of the former to attract MNCs. These dynamics can occur both between and within countries. Therefore, considering the location 
determinants of FDI in a regional perspective, thus opening the black box of country level analyses, paves the way for policy measures at national (or supranational) scale targeted at reinforcing the profile of specific lagging behind locations in participating in global production.

Author Contribution Kleineick gathered and analysed the data. He also wrote the draft paper under guidance of Smit. Ascani rewrote and severely abridged the paper; he also undertook most of the revision. Smit finalized the paper and ran the analyses in the revision stage. All authors read and approved the final manuscript.

Funding Open Access funding provided by Utrecht University.

Open Access This article is licensed under a Creative Commons Attribution 4.0 International License, which permits use, sharing, adaptation, distribution and reproduction in any medium or format, as long as you give appropriate credit to the original author(s) and the source, provide a link to the Creative Commons licence, and indicate if changes were made. The images or other third party material in this article are included in the article's Creative Commons licence, unless indicated otherwise in a credit line to the material. If material is not included in the article's Creative Commons licence and your intended use is not permitted by statutory regulation or exceeds the permitted use, you will need to obtain permission directly from the copyright holder. To view a copy of this licence, visit http://creativecommons.org/licenses/by/4. $0 \%$

\section{Appendix}

Table 7 Variable definition and source

\begin{tabular}{|c|c|c|c|c|}
\hline $\begin{array}{l}\text { Set of } \\
\text { factors }\end{array}$ & Variable & Proxy & $\begin{array}{l}\text { Spatial } \\
\text { Units }\end{array}$ & Data (year) \\
\hline \multirow{4}{*}{$\begin{array}{l}\text { Dependent: } \\
\text { Foreign } \\
\text { sub- } \\
\text { sidiaries } \\
\text { of } \\
\text { MNCs }\end{array}$} & \multirow{2}{*}{$\begin{array}{l}\text { Location } \\
\text { decision of } \\
\text { Greenfield } \\
\text { projects }\end{array}$} & Number of Greenfield projects ${ }^{a}$ & NUTS3 & $\begin{array}{l}\text { Amadeus } \\
(2012-2017)\end{array}$ \\
\hline & & $\begin{array}{l}\text { Number of employees (greenfield } \\
\text { projects) }^{a}\end{array}$ & NUTS3 & $\begin{array}{l}\text { Amadeus } \\
(2012-2017)\end{array}$ \\
\hline & \multirow{2}{*}{$\begin{array}{l}\text { Location } \\
\text { decision of } \\
\text { Merge \& } \\
\text { Acquisition } \\
\text { projects }\end{array}$} & Number of $M \& A$ projects $^{a}$ & NUTS3 & $\begin{array}{l}\text { Amadeus } \\
(2012-2017)\end{array}$ \\
\hline & & Number of employees $(M \& A s)^{a}$ & NUTS3 & $\begin{array}{l}\text { Amadeus } \\
(2012-2017)\end{array}$ \\
\hline \multirow{6}{*}{$\begin{array}{l}\text { Traditional } \\
\text { location } \\
\text { factors }\end{array}$} & $\begin{array}{l}\text { National } \\
\text { market size }\end{array}$ & GDP per capita & NUTSO & $\begin{array}{l}\text { Eurostat (2015) } \\
\text { [med_ec1] }\end{array}$ \\
\hline & $\begin{array}{l}\text { Regional } \\
\text { market size }\end{array}$ & $\begin{array}{l}\text { Regional GDP per capita at current } \\
\text { price }\end{array}$ & NUTS3 & $\begin{array}{l}\text { Eurostat (2015) } \\
\text { [nama_10r_3gdp] }\end{array}$ \\
\hline & $\begin{array}{l}\text { Regional } \\
\text { market poten- } \\
\text { tial }\end{array}$ & $\begin{array}{l}\text { Regional GDP growth at current } \\
\text { price (percentage change on previ- } \\
\text { ous year) }\end{array}$ & NUTS3 & $\begin{array}{l}\text { Eurostat } \\
(2014 / 2015) \\
\text { [nama_10r_3gdp] }\end{array}$ \\
\hline & $\begin{array}{l}\text { Regional } \\
\text { (un-) } \\
\text { employment }\end{array}$ & $\begin{array}{l}\text { Total Regional Employment } \\
\text { per } 1000 \text { persons (age class: } \\
15-74 \text { years) }{ }^{a}\end{array}$ & NUTS3 & $\begin{array}{l}\text { Eurostat }(2014)^{\mathrm{b}} \\
\text { [nama_10r_ } \\
\text { 3empers] }\end{array}$ \\
\hline & Labour costs & Disposable income per capita & NUTS2 & $\begin{array}{l}\text { Eurostat }(2014)^{\mathrm{b}} \\
{[\operatorname{tgs} 00026]}\end{array}$ \\
\hline & $\begin{array}{l}\text { Population } \\
\text { Density }\end{array}$ & Inhabitants per $\mathrm{km}^{2}$ & NUTS3 & $\begin{array}{l}\text { Eurostat }(2016)^{\mathrm{b}} \\
\text { [demo_r_d3dens] }\end{array}$ \\
\hline
\end{tabular}


Table 7 (Continued)

\begin{tabular}{|c|c|c|c|c|}
\hline $\begin{array}{l}\text { Set of } \\
\text { factors }\end{array}$ & Variable & Proxy & $\begin{array}{l}\text { Spatial } \\
\text { Units }\end{array}$ & Data (year) \\
\hline \multirow[t]{4}{*}{$\begin{array}{l}\text { Innovation } \\
\text { capabili- } \\
\text { ties }\end{array}$} & $\begin{array}{l}\text { Human Capi- } \\
\text { tal }\end{array}$ & $\begin{array}{l}\text { Participation rate in tertiary ed- } \\
\text { ucation (level 5-8; age class: } \\
25-64 \text { years) }\end{array}$ & NUTS2 & $\begin{array}{l}\text { Eurostat (2015) } \\
\text { [edat_lfse_04] }\end{array}$ \\
\hline & \multirow{2}{*}{$\begin{array}{l}\text { Regional } \\
\text { innovative } \\
\text { dynamism }\end{array}$} & $\begin{array}{l}\text { Patent applications to the EPO per } \\
\text { million inhabitants }\end{array}$ & NUTS3 & $\begin{array}{l}\text { Eurostat }(2011)^{\mathrm{b}} \\
\text { [pat_ep_rtot] }\end{array}$ \\
\hline & & $\begin{array}{l}\text { Instrumental } R \& D \text { expenditure per } \\
\text { inhabitant (in Euro) }\end{array}$ & NUTS2 & $\begin{array}{l}\text { Eurostat }(2013)^{\mathrm{b}} \\
\text { [rd_e_gerdreg] }\end{array}$ \\
\hline & $\begin{array}{l}\text { Regional } \\
\text { productivity }\end{array}$ & Gross Value Added ${ }^{a}$ & NUTS3 & $\begin{array}{l}\text { Eurostat }(2014)^{\mathrm{b}} \\
\text { [nama_10r_3gva] }\end{array}$ \\
\hline \multirow[t]{4}{*}{$\begin{array}{l}\text { Institutional } \\
\text { factors }\end{array}$} & $\begin{array}{l}\text { Government } \\
\text { corruption }\end{array}$ & Corruption Perception Index & NUTS0 & $\begin{array}{l}\text { Transparency } \\
\text { International } \\
(2017)\end{array}$ \\
\hline & $\begin{array}{l}\text { Political } \\
\text { Stability }\end{array}$ & $\begin{array}{l}\text { Political Stability and Absence of } \\
\text { Violence/Terrorism Index }\end{array}$ & NUTS0 & $\begin{array}{l}\text { World Bank } \\
(2016)\end{array}$ \\
\hline & \multirow[t]{2}{*}{ Taxation } & Statutory corporate income tax rate & NUTS0 & $\begin{array}{l}\text { Spengel et al. } \\
(2017)\end{array}$ \\
\hline & & Effective average tax rate & NUTS0 & $\begin{array}{l}\text { Spengel et al. } \\
(2017)\end{array}$ \\
\hline
\end{tabular}



${ }^{b}$ All Eurostat data can be accessed by dataset name from https://ec.europa.eu/eurostat/data/database

Table 8 Sectors included

\begin{tabular}{lll}
\hline Business activity & NACE Rev. 2 & Description \\
\hline Manufacturing & B, C, D \& E & Manufacturing, mining and quarrying and other industry \\
& F & Construction \\
Service & K & Financial and insurance activities \\
& M \& N & Professional, scientific, technical, administration and support \\
& activities \\
& R, S, T \& U & Other services \\
\hline
\end{tabular}


Table 9 Results including Corruption. See Table 2 for full names of variables

\begin{tabular}{|c|c|c|c|c|c|c|}
\hline & Nr_GI & GI_MANU & GI_SERVICE & Nr_MA & MA_MANU & MA_SERVICE \\
\hline \multirow[t]{2}{*}{$\overline{\text { (Intercept) }}$} & 0.3518 & $4.9169^{*}$ & -4.9769 & -4.3592 & 0.9693 & -2.2659 \\
\hline & $(14.1319)$ & $(1.9597)$ & (10.5009) & $(4.2002)$ & $(1.7828)$ & $(1.2890)$ \\
\hline \multicolumn{7}{|c|}{ Traditional determinants } \\
\hline \multirow{2}{*}{$\begin{array}{l}l G D P_{-} \\
P C\end{array}$} & $0.0011^{* * *}$ & $0.0001^{* * *}$ & $0.0006^{* * *}$ & $0.0004^{* * *}$ & $0.0001^{* * *}$ & $0.0002^{* * *}$ \\
\hline & $(0.0001)$ & $(0.0000)$ & $(0.0001)$ & $(0.0000)$ & $(0.0000)$ & $(0.0000)$ \\
\hline \multirow{2}{*}{$\begin{array}{l}l G D P_{-} \\
G R\end{array}$} & -0.0029 & -0.0003 & -0.0014 & -0.0011 & -0.0000 & -0.0005 \\
\hline & $(0.0054)$ & $(0.0005)$ & $(0.0045)$ & $(0.0016)$ & $(0.0005)$ & $(0.0007)$ \\
\hline \multirow{2}{*}{$\begin{array}{l}l E M P L_{-} \\
A L L\end{array}$} & $0.0700^{* * *}$ & $0.0089^{* * *}$ & $0.0357^{* * *}$ & $0.0550^{* * *}$ & $0.0149^{* * *}$ & $0.0153^{* * *}$ \\
\hline & $(0.0048)$ & $(0.0004)$ & $(0.0040)$ & $(0.0014)$ & $(0.0004)$ & $(0.0006)$ \\
\hline \multirow[t]{2}{*}{$r I N C$} & -0.0001 & $0.0002^{* * *}$ & $-0.0011^{*}$ & 0.0002 & $0.0002^{* * *}$ & $-0.0002^{* * *}$ \\
\hline & $(0.0005)$ & $(0.0001)$ & $(0.0005)$ & $(0.0002)$ & $(0.0001)$ & $(0.0001)$ \\
\hline \multirow{2}{*}{$\begin{array}{l}\text { lPOP } \\
\text { DENS }\end{array}$} & -0.0015 & $-0.0002^{* *}$ & $-0.0016^{*}$ & $-0.0007^{* *}$ & $-0.0006^{* * *}$ & -0.0000 \\
\hline & $(0.0008)$ & $(0.0001)$ & $(0.0007)$ & $(0.0002)$ & $(0.0001)$ & $(0.0001)$ \\
\hline \multicolumn{7}{|c|}{ Innovation capabilities } \\
\hline \multirow[t]{2}{*}{$r E D U$} & $0.6836^{* *}$ & 0.0262 & 0.2161 & $0.2795^{* * *}$ & 0.0210 & $0.0650^{*}$ \\
\hline & $(0.2321)$ & $(0.0228)$ & $(0.1930)$ & $(0.0678)$ & $(0.0227)$ & $(0.0257)$ \\
\hline \multirow{2}{*}{$\begin{array}{l}l P A T_{-} \\
A P\end{array}$} & $-0.0226^{* * *}$ & $-0.0029^{* * *}$ & $-0.0101^{*}$ & $-0.0065^{* * *}$ & $-0.0016^{* *}$ & $-0.0020^{* *}$ \\
\hline & $(0.0058)$ & $(0.0005)$ & $(0.0049)$ & $(0.0017)$ & $(0.0005)$ & $(0.0007)$ \\
\hline \multirow[t]{2}{*}{$r R N D E X$} & $-2.0962^{*}$ & -0.1316 & -1.1485 & $-0.6565^{*}$ & $-0.2311^{*}$ & -0.1866 \\
\hline & $(0.9436)$ & $(0.0885)$ & $(0.7809)$ & $(0.2729)$ & $(0.0897)$ & $(0.1115)$ \\
\hline \multirow{2}{*}{$\begin{array}{l}r G V A_{-} \\
M A N U\end{array}$} & - & -51.2785 & - & - & $111.2951^{*}$ & - \\
\hline & - & $(44.8350)$ & - & - & $(45.6016)$ & - \\
\hline \multirow{2}{*}{$\begin{array}{l}r G V A_{-} \\
\text {SERVICE }\end{array}$} & - & - & $593.7302^{* *}$ & - & - & $112.7515^{* * *}$ \\
\hline & - & - & $(206.1815)$ & - & - & $(29.5246)$ \\
\hline \multicolumn{7}{|c|}{ Insitutitional factors } \\
\hline \multirow[t]{2}{*}{$n P S T$} & 10.7114 & -0.2764 & 8.4776 & 3.1931 & 0.2228 & 1.6901 \\
\hline & $(9.3775)$ & $(1.3731)$ & (6.7959) & $(2.8015)$ & $(1.2382)$ & $(0.8013)$ \\
\hline \multirow[t]{2}{*}{$n E A T R$} & -0.7769 & $-0.2039^{*}$ & -0.0289 & $-0.4134^{*}$ & -0.1481 & -0.0301 \\
\hline & $(0.5382)$ & $(0.0772)$ & $(0.3984)$ & $(0.1605)$ & $(0.0699)$ & $(0.0478)$ \\
\hline \multirow[t]{2}{*}{$n C O R$} & $-0.4781^{*}$ & $-0.0807^{*}$ & -0.1154 & $-0.1480^{*}$ & -0.0373 & -0.0341 \\
\hline & $(0.2166)$ & $(0.0298)$ & $(0.1643)$ & $(0.0643)$ & $(0.0272)$ & $(0.0204)$ \\
\hline AIC & $10,264.9878$ & 5040.5120 & 9869.9594 & 7647.1619 & 5076.0657 & 5788.8976 \\
\hline $\mathrm{BIC}$ & $10,334.4327$ & 5114.9172 & 9944.3646 & 7716.6067 & 5150.4710 & 5863.3028 \\
\hline $\begin{array}{l}\text { Log Like- } \\
\text { lihood }\end{array}$ & -5118.4939 & -2505.2560 & -4919.9797 & -3809.5809 & -2523.0329 & -2879.4488 \\
\hline Num. obs & 1054 & 1054 & 1054 & 1054 & 1054 & 1054 \\
\hline $\begin{array}{l}\text { Num. } \\
\text { groups }\end{array}$ & 17 & 17 & 17 & 17 & 17 & 17 \\
\hline
\end{tabular}

*** $p<0.001,{ }^{* *} p<0.01, \stackrel{*}{p}<0.05$ 
Table 10 Results regional Patent Intensity. See Table 2 for full names of variables

\begin{tabular}{|c|c|c|}
\hline & Model 1 & Model 2 \\
\hline \multirow[t]{2}{*}{$\overline{\text { (Intercept) }}$} & 1.9665 & -0.4746 \\
\hline & $(1.5018)$ & $(1.7798)$ \\
\hline \multicolumn{3}{|c|}{ Traditional determinants } \\
\hline \multirow[t]{2}{*}{$n G D P \_P C$} & $-0.0001^{* * *}$ & -0.0000 \\
\hline & $(0.0000)$ & $(0.0000)$ \\
\hline \multirow[t]{2}{*}{$l G D P_{-} P C$} & $0.0001^{* * *}$ & $0.0001^{* * *}$ \\
\hline & $(0.0000)$ & $(0.0000)$ \\
\hline \multirow[t]{2}{*}{$l G D P \_G R$} & -0.0003 & -0.0000 \\
\hline & $(0.0005)$ & $(0.0005)$ \\
\hline \multirow[t]{2}{*}{$l E M P L \_A L L$} & $0.0089^{* * *}$ & $0.0148^{* * *}$ \\
\hline & $(0.0004)$ & $(0.0004)$ \\
\hline \multirow[t]{2}{*}{$r I N C$} & $0.0002^{* * *}$ & $0.0003^{* * *}$ \\
\hline & $(0.0000)$ & $(0.0000)$ \\
\hline \multirow[t]{2}{*}{ IPOP_DENS } & $-0.0002^{* *}$ & $-0.0006^{* * *}$ \\
\hline & $(0.0001)$ & $(0.0001)$ \\
\hline \multicolumn{3}{|c|}{ Innovation capabilities } \\
\hline \multirow[t]{2}{*}{$r E D U$} & 0.0310 & 0.0060 \\
\hline & $(0.0206)$ & $(0.0218)$ \\
\hline \multirow[t]{2}{*}{$l P A T_{-} A P$} & $-0.0030^{* * *}$ & $-0.0013^{* *}$ \\
\hline & $(0.0005)$ & $(0.0005)$ \\
\hline \multirow[t]{2}{*}{$r R N D E X$} & $-0.1738^{*}$ & -0.1371 \\
\hline & $(0.0794)$ & $(0.0815)$ \\
\hline \multicolumn{3}{|c|}{ Institutional factors } \\
\hline \multirow[t]{2}{*}{$n P S T$} & -0.3787 & 0.2720 \\
\hline & $(0.9805)$ & $(1.1730)$ \\
\hline \multirow[t]{2}{*}{$n E A T R$} & $-0.1518^{*}$ & -0.1421 \\
\hline & $(0.0602)$ & $(0.0718)$ \\
\hline AIC & 5031.6851 & 5079.1405 \\
\hline $\mathrm{BIC}$ & 5101.1299 & 5148.5853 \\
\hline Log Likelihood & -2501.8425 & -2525.5702 \\
\hline Num. obs & 1054 & 1054 \\
\hline Num. groups & 17 & 17 \\
\hline
\end{tabular}

*** $p<0.001,{ }^{* *} p<0.01,{ }^{*} p<0.05$ 


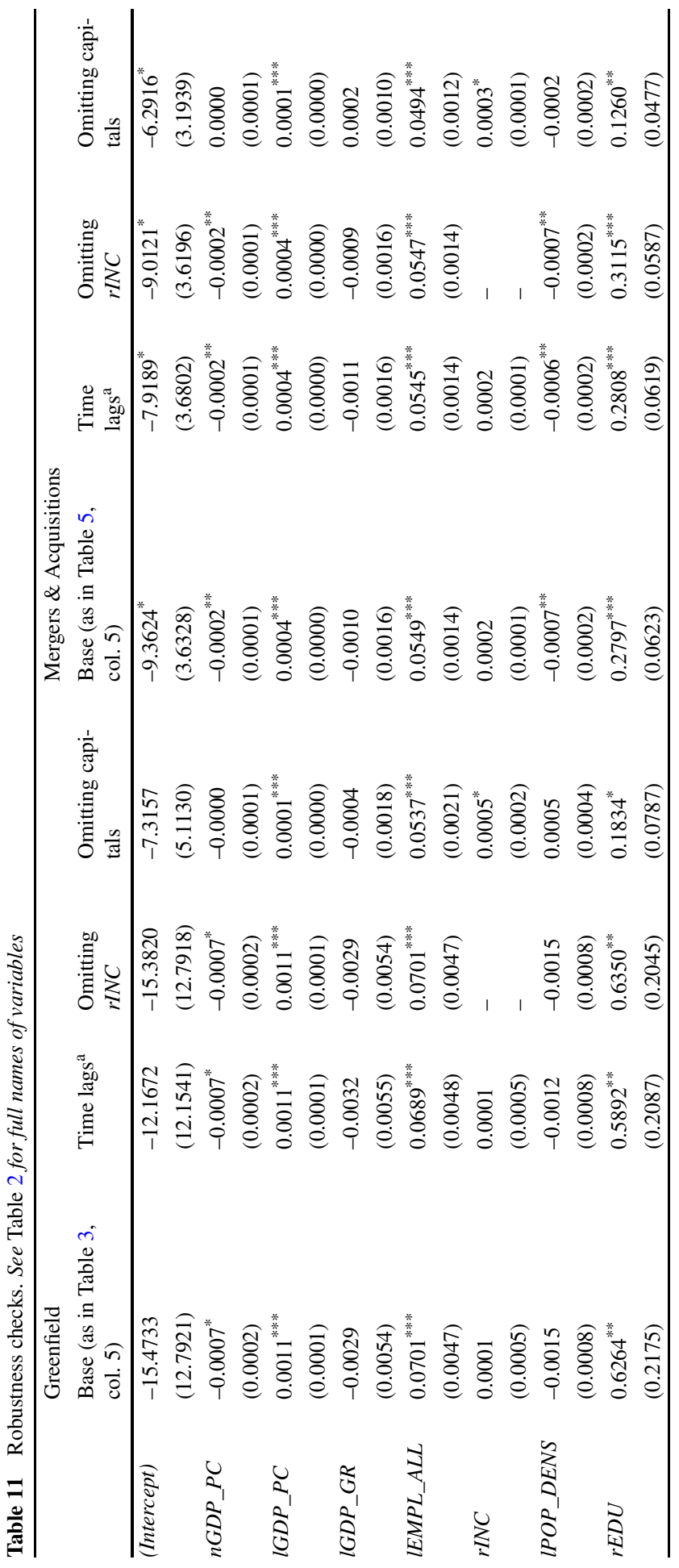




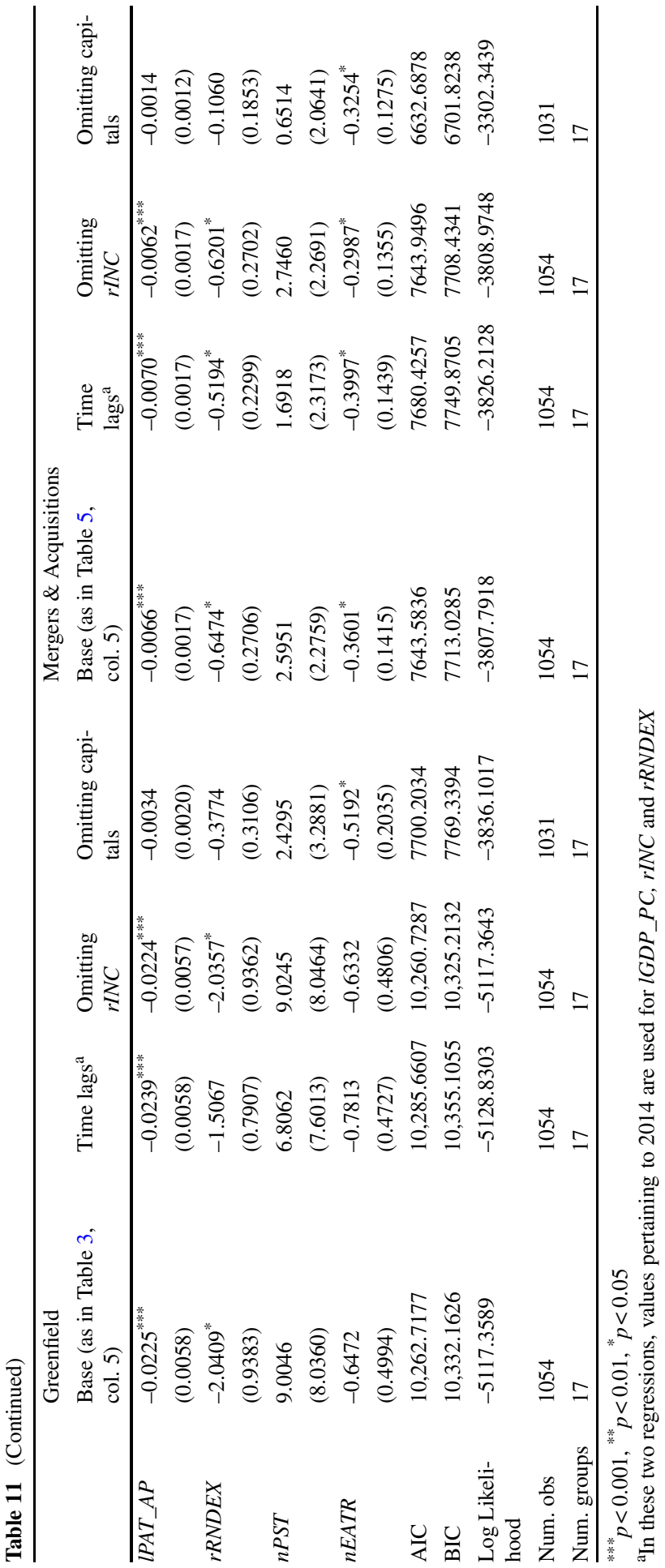




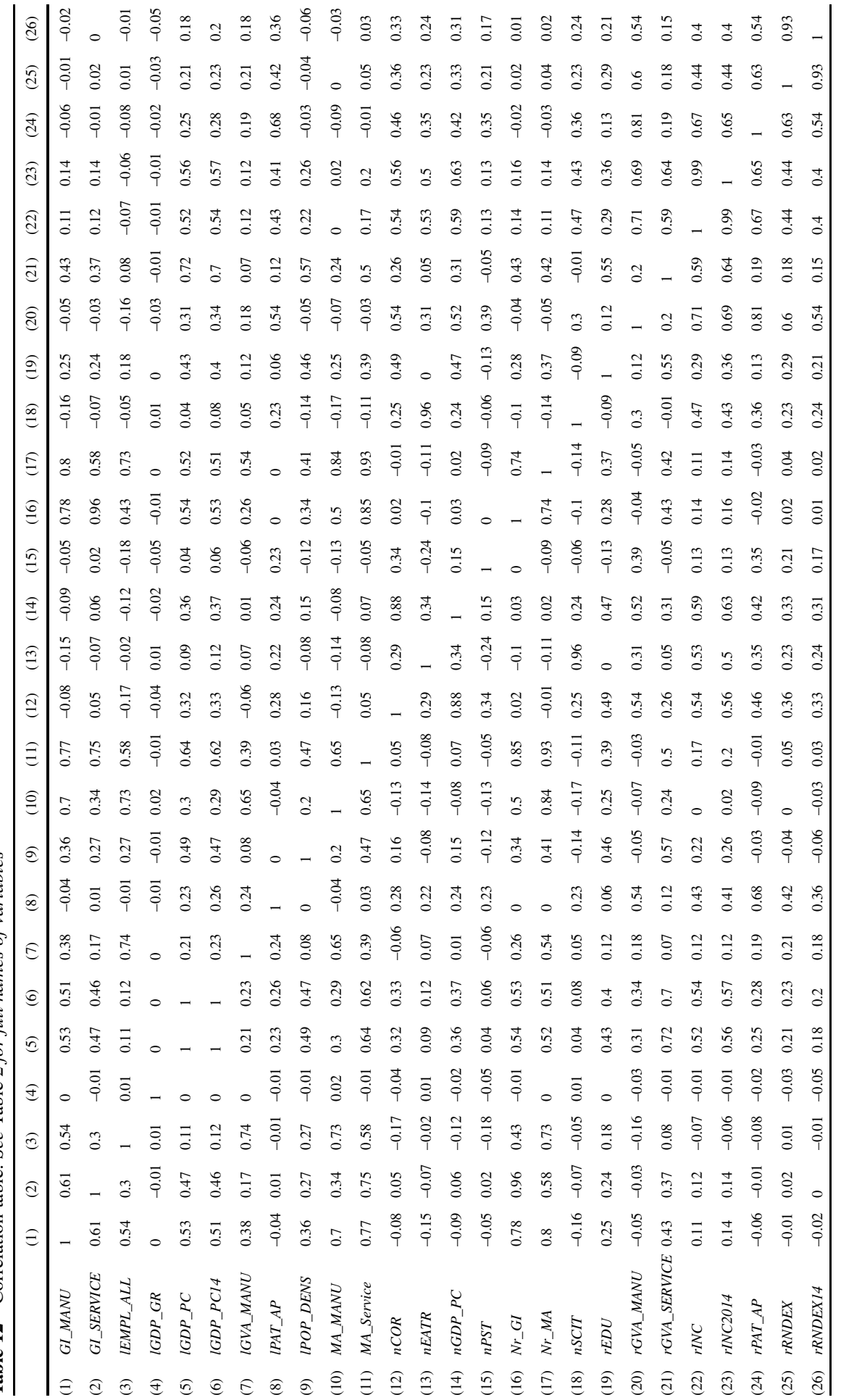




\section{References}

Andersson U, Johanson J, Vahlne JE (1997) Organic acquisitions in the internationalization process of the business firm. Manag Int Rev 37:67-84

Ang JB (2008) Determinants of foreign direct investment in Malaysia. J Policy Model 30(1):185-189

Ascani A (2018) The takeover selection decisions of multinational enterprises: empirical evidence from European target firms. J Econ Geogr 18(6):1227-1252

Ascani A, Gagliardi L (2015) Inward FDI and local innovative performance. An empirical investigation on Italian provinces. Rev Reg Res 35:29-47

Ascani A, Balland PA, Morrison A (2019) Heterogeneous foreign direct investment and local innovation in Italian provinces. Struct Chang Econ Dyn. https://doi.org/10.1016/j.strueco.2019.06.004

Ascani A, Crescenzi R, Iammarino S (2016) Economic institutions and the location strategies of European multinationals in their geographic neighbourhood. Econ Geog 92(4):401-429

Asiedu E (2006) Foreign direct investment in Africa: The role of natural resources, market size, government policy, institutions and political instability. World Econ 29(1):63-77

Bartik T (1985) Business location decisions in the United States: Estimates of the effects of unionization, taxes, and other characteristics of states. J Bus Econ Stat 3:14-22

Basile R (2004) Acquisition versus greenfield investment: the location of foreign manufacturers in Italy. Reg Sci Urban Econ 34(1):3-25

Basile R, Castellani D, Zanfei A (2008) Location choices of multinational firms in Europe: the role of EU cohesion policy. J Int Econ 74(2):328-340

Becker J, Fuest C (2011) Tax competition-Greenfield investment versus mergers and acquisitions. Reg Sci Urban Econ 41(5):476-486

Bellak C, Leibrecht M (2009) Do low corporate income tax rates affect FDI? Evidence from central and east European countries. Appl Econ 41:2691-2703

Bellak C, Leibrecht M, Riedl A (2008) Labour costs and FDI flows into Central and Eastern European Countries: a survey of the literature and empirical evidence. Struct Chang Econ Dyn 19(1):17-37

Bertrand O, Mucchielli JL, Zitouna H (2007) Location choices of multinational firms: the case of mergers and acquisitions. J Econ Integr 22:181-209

Biswas R (2002) Determinants of foreign direct investment. Rev Dev Econ 6(3):492-504

Boschma R (2005) Proximity and innovation: a critical assessment. Reg Stud 39(1):61-74

Botrić V, Škuflić L (2006) Main determinants of foreign direct investment in the southeast European countries. Trans Stud Rev 13(2):359-377

Brakman S, Garretsen H, van Marrewijk C (2007) Cross-border mergers and acquisitions: The facts as a guide for international economics. In International Mergers and Acquisitions Activity Since 1990 (pp. 23-49). Academic Press: Boston

Buettner T, Ruf M (2007) Tax incentives and the location of FDI: Evidence from a panel of German multinationals. Int Tax Public Finance 14(2):151-164

Cantwell J (1989) Technological innovation and multinational corporations. Basil Blackwell, Oxford

Cantwell J, Iammarino S (2003) Multinational corporations and European regional systems of innovation. Routledge, London

Cantwell J, Piscitello L (2005) Recent location of foreign-owned research and development activities by large multinational corporations in the European regions: the role of spillovers and externalities. Reg Stud 39(1):1-16

Cantwell J, Santangelo GD (2002) M\&As and the global strategies of TNCs. Dev Econ 40(4):400-434

Capello R, Fratesi U, Resmini L (2011) Globalization and regional growth in Europe: past trends and future scenarios. Springer, Berlin Heidelberg

Clague C, Keefer P, Knack S, Olson M (1994) Institutions and economic performance: A new look at democracies and growth. In: Draft prepared for the institutional reform and the informal sector conference on economic and political institutions for sustainable development

Cleeve E (2008) How effective are fiscal incentives to attract FDI to Sub-Saharan Africa? J Dev Areas 42(1):135-153

Crescenzi R, Pietrobelli C, Rabellotti R (2014) Innovation drivers, value chains and multinational corporations in Europe. J Econ Geogr 14:1053-1086

Crozet M, Mayer T, Mucchielli JL (2004) How do firms agglomerate? A study of FDI in France. Reg Sci Urban Econ 34(1):27-54

Defever F (2006) Functional fragmentation and the location of multinational firms in the enlarged Europe. Reg Sci Urban Econ 36(5):658-677 
De Mooij RA, Ederveen S (2006) What a difference does it make? Understanding the empirical literature on taxation and international capital flows. European Economy Economic Papers, no. 261

Devereux MP, Griffith R (1998a) Taxes and the location of production: evidence from a panel of US multinationals. J Public Econ 68(3):335-367

Devereux MP, Griffith R (1998b) The taxation of discrete investment choices (No. W98/16). IFS working papers

Dicken P (2007) Global shift: mapping the changing contours of the world economy, 5th edn. SAGE, London

Disdier AC, Mayer T (2004) How different is Eastern Europe? Structure and determinants of location choices by French firms in Eastern and Western Europe. J Comp Econ 32:280-296

Du J, Lu Y, Tao Z (2008) Economic institutions and FDI location choice: evidence from US multinationals in China. J Comp Econ 36:412-429

Dunning JH (1977) Trade, location of economic activity and the multinational enterprise: a search for an eclectic approach. In: Ohlin B, Hesselborn PO, Wijkman PM (eds) The International Allocation of Economic Activity. Macmillan, London, pp 19-51

Dunning JH (1979) Explaining changing pattern of international production: in defence of eclectic theory. Oxf Bull Econ Stat 41(4):269-296

Dunning JH (2013) Multinationals, Technology \& Competitiveness. RLE International Business, vol 13. Routledge, London/New York

Dunning JH, Lundan S (2008) Multinational Enterprises and the Global Economy. Edward Elgar, Cheltenham

Eurostat (2006) NACE Rev.2-Statistical classification of economic activities in the European Community. Office for Official Publications of the European Communities, Luxembourg

Eurostat (2015) Regions in the European Union. Nomenclature of territorial units for statistics NUTS2013. Office for Official Publications of the European Communities, Luxembourg

Eurostat (2018) TERCET NUTS-Postal Codes Matching Tables. https://ec.europa.eu/eurostat/tercet/ flatfiles.do. Last access date: 6 April 2020.

Gereffi G, Korzeniewicz M (1994) Commodity chains and global capitalism. Praeger, Westport

Gorzelak G, Smętkowski M (2010) Regional development dynamics in central and eastern European countries. In: Gorzelak G, Bachtler J, Smętkowski M (eds) Regional development in central and eastern Europe: development processes and policy challenges. Routledge Contemporary Russia and Eastern Europe Series. Routledge, Abingdon

Guadalupe M, Kuzmina O, Thomas C (2012) Innovation and foreign ownership. Am Econ Rev 102:35943627

Guimaraes P, Figueiredo O, Woodward D (2000) Agglomeration and the location of foreign direct investment in Portugal. J Urban Econ 47:115-135

Hartman DG (1984) Tax policy and foreign direct investment in the United States. Nat Tax J 37(4):475-487

Head CK, Mayer T (2004) Market potential and the location of Japanese investments in the European Union. Rev Econ Stat 86:949-972

Head CK, Ries JC, Swenson DL (1995) Agglomeration benefits and location choice: evidence from Japanese manufacturing investment in the United States. J Int Econ 38:223-247

Head CK, Ries JC, Swenson DL (1999) Attracting foreign manufacturing: investment promotion and agglomeration. Reg Sci Urban Econ 29:197-218

Hennart JF, Park YR (1993) Greenfield vs. acquisition: The strategy of Japanese investors in the United States. Manage Sci 39(9):1054-1070

Hennart JF, Park YR (1994) Location, governance, and strategic determinants of Japanese manufacturing investment in the United States. Strat Mgmt J 15(6):419-436

Hlavac M (2018) Stargazer: well-formatted regression and summary statisitcs tables. R package (version 5.2.1.). https://CRAN.R-project.org/package=stargazer, last access date May 2018

Hox JJ, Moerbeek M, van de Schoot R (2017) Multilevel analysis: Techniques and applications. Routledge, New York

Iammarino S (2018) FDI and regional development policy. J Int Bus Policy 1(3-4):157-183

Iammarino S, McCann P (2013) Multinationals and economic geography. In: Elgar E (ed) Chapter 7: multinationals, Connectivity, global cities. Edward Elgar, Cheltenham, pp 284-319

Javororcik BS, Kaminski B (2009) How to attract FDI and maximize its benefits. In: Winiecki J (ed) Competitivness of New Europe. Routledge, London/New York

Kogut B, Zander U (1992) Knowledge of the Firm, Combinative Capabilities, and the Replication of Technology. Organ Sci 3(3):383-397 
Linders G-J, de Groot HLF (2006) Estimation of the gravity equation in the presence of zero flows. Tinbergen Institute Discussion Paper No. 06-072/3

Liu X, Zou H (2008) The impact of greenfield FDI and mergers and acquisitions on innovation in Chinese high-tech industries. J World Bus 43(3):352-364

Maas CJ, Hox JJ (2005) Sufficient sample sizes for multilevel modeling. Methodology 1(3):86

Marshall A (1920) Principles of economics. Macmillan, London

Miskinis A, Byrka M (2014) The role of investment promotion agencies in attracting foreign direct investment. Ekonomika 93(4):41-57

Mohamed SE, Sidiropoulos MG (2010) Another look at the determinants of foreign direct investment in MENA countries: an empirical investigation. J Econ Dev 35(2):75-95

Neary JP (2004) Cross-border mergers as instruments of comparative advantage. Discussion Paper No. 4325. CEPR, London

Neuhaus M (2005) FDI: the growth engine in central and eastern Europe. Dtsch Bank Res, EU Monitor 26:14-20

Newburry W, Zeira Y (1997) Generic differences between equity international joint ventures (EIJVs), international acquisitions (IAs) and international greenfield investments (IGIs): Implications for parent companies. J World Bus 32(2):87-102

Nocke V, Yeaple S (2007) Cross-border mergers and acquisitions vs. greenfield foreign direct investment: the role of firm heterogeneity. J Int Econ 72(2):336-365

OECD (2002) Foreign direct investment for development. Maximising benfitis, minimising costs. OECD, Paris, p 3 (https://www.oecd.org/investment/investmentfordevelopment/1959815.pdf.)

Ó Huallacháin B, Reid N (1997) Acquisition versus greenfield investment: the location and growth of Japanese manufacturers in the United States. Reg Stud 31(4):403-416

Petrakos G, Economou D (2002) The spatial aspects of development in Southeastern Europe. Spatium $8: 1-13$

Pike A, Rodriguez-Pose A, Tomaney J (2006) Local and regional development. Routledge, London

Py L, Hatem F (2009) Internationalisation et localisation des services: Une analyse sectorielle et fonctionnelle appliquée aux firmes multinationales en Europe. Econ Et Stat 426(1):67-95

Raff H, Ryan M, Stälher F (2009) The choice of market entry mode: Greenfield investment, M\&A and joint venture. Int Rev Econ Finance 18(1):3-10

Schneider F, Frey BS (1985) Economic and political determinants of foreign direct investment. World Dev 13(2):161-175

Spengel C, Schmidt F, Heckemeyer JF, Nicolay K et al (2017) Effective tax levels using the Devereux/ Griffith methodology—update 2017. ZEW, Mannheim

Traistaru I, Nijkamp P, Resmini L (eds) (2003) The emerging economic geography in EU accession countries. Ashgate Publishing Limited, Aldershot

Transparency International (2017) Corruption Perceptions Index 2017. www.transparency.org/cpi, last accessed April 2020

Voget J (2011) Relocation of headquarters and international taxation. J Public Econ 95:1067-1081

Wang A (2009) The choice of market entry mode: cross-border M\&A or greenfield investment. Int J Bus Manag 4(5):241

Wang M (2009) Manufacturing FDI and economic growth: evidence from Asian economies. Appl Econ 41(8):991-1002

Wang M, Wong S (2009) What drives economic growth? The case of cross-border M\&A and Greenfield FDI activities. Kyklos 62(2):316-330

Wheeler D, Mody A (1992) International investment location decisions: the case of US firms. J Int Econ 33(1-2):57-76

Wijeweera A, Dollery B (2009) Host country corruption level and foreign direct investments inflows. Int J Trade Glob Mark 2(2):168-178

Woodward DP (1992) Locational determinants of Japanese manufacturing start-ups in the United States. South Econ J 58:690-708

World Bank (2016) Worldwide Governance Indicators. http://info.worldbank.org/governance/wgi/\#home, last access date April 2020

WTO (1996) Foreign direct investment seen as primary motor of globalization, says WTO Director-General. WTO Press Release, vol 42

Yeung HW, Coe NM (2015) Toward a Dynamic Theory of Global Production Networks. Econ Geogr 91:29-58

Publisher's Note Springer Nature remains neutral with regard to jurisdictional claims in published maps and institutional affiliations. 